\title{
Omega 3 fatty acids on child growth, visual acuity and neurodevelopment
}

\author{
Cristina Campoy ${ }^{1 *}$, M ${ }^{\mathbf{a}}$ Victoria Escolano-Margarit ${ }^{1}$, Tania Anjos ${ }^{1}$, Hania Szajewska ${ }^{2}$ and Ricardo Uauy ${ }^{3}$ \\ ${ }^{1}$ Department of Paediatrics, School of Medicine, University of Granada Avda. de Madrid, 11-18012 Granada, Spain \\ ${ }^{2}$ Department of Paediatrics, The Medical University of Warsaw, Warsaw, Poland \\ ${ }^{3}$ Department of Public Health Nutrition, London School of Hygiene and Tropical Medicine, University of London, \\ Kepple St, London WC1E 7HT, UK
}

\begin{abstract}
The aim of this review is to evaluate the effects of omega-3 long chain polyunsaturated fatty acids (n-3 LCPUFA) supplementation in pregnant and lactating women and infants during postnatal life, on the visual acuity, psychomotor development, mental performance and growth of infants and children. Eighteen publications (11 sets of randomized control clinical trial [RCTs]) assessed the effects of the n-3 LCPUFA supplementation during pregnancy on neurodevelopment and growth, in the same subjects at different time points; 4 publications ( 2 data sets from RCTs) addressed physiological responses to n-3 LCPUFA supplementation during pregnancy \& lactation and 5 publications ( 3 data sets from RCTs) exclusively during lactation. Some of these studies showed beneficial effects of docosahexaenoic acid (DHA) supplementation during pregnancy and/or lactation especially on visual acuity outcomes and some on long-term neurodevelopment; a few, showed positive effects on growth. There were also 15 RCTs involving term infants who received infant formula supplemented with DHA, which met our selection criteria. Many of these studies claimed a beneficial effect of such supplementation on visual, neural, or developmental outcomes and no effects on growth. Although new well designed and conducted studies are being published, evidence from RCTs does not demonstrate still a clear and consistent benefit of n-3 LCPUFA supplementation during pregnancy and/or lactation on term infants growth, neurodevelopment and visual acuity. These results should be interpreted with caution due to methodological limitations of the included studies.
\end{abstract}

Key words: omega-3 fatty acids: pregnancy: lactation: infant formula: term infants: neurodevelopment: visual acuity: growth

\section{Introduction}

Docosahexaenoic acid (DHA) and arachidonic acid (AA) are important to foetal and infant growth and development. Observational and intervention studies provide consistent evidence that maternal dietary and circulating DHA is an important determinant of foetal blood concentrations of $\mathrm{DHA}^{(1-6)}$. Although linoleic acid (LA) and $\alpha$-linolenic acid (ALA), and preformed long chain polyunsaturated fatty acids (LCPUFAs), can be transported through the placenta, there is a preferential transfer of the latter forms ${ }^{(6,7)}$. Several studies have assessed the effect of prenatal LCPUFA dietary supplementation on pregnancy outcome, aiming to improve it-i.e., preventing preeclampsia, prolonging gestation, preventing preterm birth, and improving foetal growth ${ }^{(3,8-9)}$.

On the other hand, the importance of DHA in central nervous system (CNS) development is one of the most intensely studied areas ${ }^{(10-14)}$. DHA functions in neurogenesis, neurotransmission and protection against oxidative stress ${ }^{(15)}$. AA is also important for infant growth and development. n-3 and n-6 LCPUFA are critical for infant and child brain development; they are involved in numerous neuronal processes, ranging from effects on membrane fluidity to gene expression regulation $^{(16)}$. Brain accumulation of DHA starts in utero, with quantitatively marked deposition in the second half of gestation $^{(17-19)}$, coinciding with the growth spurt in the grey matter ${ }^{(19)}$. Deficiencies and imbalances of LCPUFAs are associated with impairments in cognitive and behavioural performance ${ }^{(19-20)}$.

Fish intake during pregnancy and a higher n-3 LCPUFA status at birth were associated with a better visual development in infants born at term ${ }^{(20-22)}$. However, levels of DHA and eicosapentaenoic acid (EPA) are often low in the Western $\operatorname{diet}^{(23-24)}$. It remains controversial whether LCPUFA supplementation to pregnant and breastfeeding mothers is beneficial for the development of their infants ${ }^{(25-26)}$, optimal doses for efficacy and long-term effects at different developmental ages remain to be determined. Today, there are in excess of 40 perinatal randomized controlled trials involving LCPUFA interventions assessing different aspects of early childhood development and growth ${ }^{(29)}$.

The earliest publications in human infants from the early 1990s showed that preterm infants fed a formula supplemented with n-3 LCPUFA, mainly as DHA, had improved retinal sensitivity and visual acuity compared with preterm 
infants fed the standard un-supplemented formulas of the day, which were low in $\mathrm{n}-3$ PUFA (most were lacking alpha-linolenic acid) and were rich in n-6 PUFA ${ }^{(28-30)}$. Other intervention studies has also provide evidence that dietary DHA improves visual, mental, and motor skill development in some preterm and term infants fed supplemented formula ${ }^{(31-34)}$. In a non-randomised observational study, term infants fed breast milk have been found to have more mature visual acuities and correlated to higher erythrocyte DHA levels than those receiving formula ${ }^{(31)}$. Evidence to suggest that breast-fed infants have a long term IQ advantage over those who have been fed formula has been evident in the literature for many years ${ }^{(35-37)}$. Moreover, we realize that the majority of comparisons between breast fed and formula-fed infants are confounded by genetic polymorphisms that affect LCP metabolism and socioeconomic factors which affect the outcomes of most studies ${ }^{(38-40)}$.

The present review was undertaken to systematically assess the evidence of short and long-term effects of n-3 LCPUFA supplementation during pregnancy and/or postnatal life on the visual acuity, psychomotor development, mental performance and growth of children.

\section{Methods}

\section{Criteria for considering studies for this review (Table 1)}

Types of interventions: inclusion criteria. All relevant RCTs with LCPUFA intervention in healthy pregnant women,

Table 1. Inclusion and exclusion criteria established for the systematic review

\begin{tabular}{cc}
\hline Inclusion criteria & RCTs designed to study the effects of n-3 \\
& LCPUFA supplementation on growth, visual \\
acuity and neurodevelopment & - Studies involving supplementation with DHA plus \\
AA or DHA alone in healthy pregnant women & Studies involving supplementation with DHA plus \\
AA or DHA alone in healthy lactating mothers \\
- Studies involving supplementation with DHA plus \\
AA or DHA alone of infant formula in healthy full- \\
term infants ( $\geq 37$ weeks gestation at birth) \\
- Study formula commenced within two weeks after \\
birth \\
- Study formula as only source of milk from the \\
time of randomisation until at least 8 weeks \\
of age \\
- A minimum of three months follow-up data \\
available on clinical outcomes of interest. \\
- Trials in women with high-risk pregnancies \\
- Trials in which precursor essential FAs \\
( $\alpha$-linolenic and linoleic acids) were used \\
in the intervention group. \\
- Title or abstract not relevant \\
- Trials which used breast milk in addition to study \\
formula during the first 8 weeks of life \\
- Trials reporting on only biochemical outcomes \\
- Certain publication types (Letters to the editor, \\
abstracts and proceedings from scientific \\
meetings)
\end{tabular}

RCTs: Randomized clinical trials; DHA: Docosahexaenoic acid; AA: Arachidonic Acid; FAs: Fatty acids. lactating mothers and healthy full-term infants ( $\geq 37$ weeks gestation at birth) were elegible for inclusion.From the randomised control trials RCTs or quasi-RCTs found in literature, only the ones designed to study the effects of n-3 LCPUFA supplementation on any standardized measures of growth, psychomotor development, mental performance and visual acuity in the offspring were selected. A trial was defined as quasi-random if the method used to allocate study pregnant women or infants to the study group was either not statistically random or was not clearly stated.

Interventions during pregnancy, lactation and with infant formula for full-term infants with DHA plus AA or DHA alone were included to be compared to those unsupplemented or receiving placebo during pregnancy or postnatally.

LCPUFA supplements could be from any source including fish oil, egg triglycerides or fungal oils. Trials in which precursor essential FAs ( $\alpha$-linolenic and linoleic acids) were used in the intervention group were not included, because intake of the precursors is far less effective with respect to LCPUFA deposition in fetal brain.

Studies involving prenatal and lactating mothers supplementation were assessed independently from studies with postnatal supplementation of infant formula.

The selection of interventions with infant formula in fullterm infants had the following criteria: 1) Study formula was commenced within two weeks after birth; 2) Study formula was the only source of milk from the time of randomisation until at least 8 weeks of age; 3) A minimum of three months follow-up data on clinical outcomes of interest was available.

Types of interventions: exclusion criteria. Trials in women with high-risk pregnancies were not included, with high-risk pregnancy being defined as one in which a condition places the mother, the developing foetus, or both at higher-thannormal risk for complications during or after pregnancy and birth (e.g., a preterm delivery during an earlier pregnancy, intrauterine growth retardation, pregnancy-induced hypertension, or multiparity).

We excluded studies if the title and abstract were not relevant; however, we obtained articles for all potentially relevant studies if the abstract contained insufficient information to warrant exclusion. All areas of disagreement were discussed by the reviewers to achieve a consensus, and taken also into account the quality assessment.

Trials which used breast milk in addition to study formula during the first 8 weeks of life were not included to address the effect of early intervention with LCPUFA in formula-fed term infants. Trials reporting on only biochemical outcomes were also excluded.

Types of outcome measures. Visual acuity: measured either using Teller cards, visual evoked potentials (VEP), electroretinography (ERG), electroencephalography (EEG) and steroacuity. Neurodevelopmental outcomes: General Quotient, Intelligent Quotient, Psychomotor Scores, Behavior and other measures of Cognitive Functions. Growth: weight, length, head circumference and/or BMI. 


\section{Search methods for identification of studies}

The search strategy included the use of a validated filter for identifying RCTs ${ }^{(41)}$ which was combined with a topic specific strategy using the following PubMed's MeSH terms: (FA OR omega-6 OR omega-3 OR n-6 OR n-3 OR eicosapentaenoic acid $O R$ EPA or docosahexaenoic acid $O R$ DHA $O R$ arachidonic acid $O R$ AA $O R$ LCPUFA $O R$ long-chain FA $O R$ essential FA $O R$ fish oil) $A N D$ (mother supplementation $O R$ pregnancy $O R$ lactation $O R$ breastfeeding $O R$ infant formula) AND (Infant $O R$ Newborn $O R$ Neonate) $A N D$ (growth $O R$ weight $O R$ length $O R$ height $O R$ head circumference) AND (cognitive function $O R$ development $O R$ neurodevelopment $O R$ psychomotor development $O R$ memory $O R$ attention $O R$ language $O R$ intelligence $O R$ cognition $O R$ visual function $O R$ visual acuity $O R$ electroretinogram $O R$ visual evoked potentials $O R$ VEP $O R$ behaviour $O R$ neurobehaviour) AND (Clinical Trial $O R$ Randomised Controlled Trial $O R$ Review). The reference lists of identified studies and key review articles, including previously published reviews, as well as, major epidemiological studies and position papers, were also searched for all studies that assessed the effects of n-3 LCPUFA supplementation on child growth, neurodevelopment and/or visual function. We performed a computerized literature search of MEDLINE (from 1966 to April 2011), EMBASE (from 1980 to April 2011), LILACS (from 1980 to April 2011) and the Cochrane Central Register of Controlled Trials (CENTRAL, the Cochrane Library (issue 4, 2011). We imposed no limit with respect to the language of publication, but certain publication types (i.e., letters to the editor, abstracts, and proceedings from scientific meetings) were excluded.

\section{Quality assessment of trials}

The assessment of the quality of the studies that met the inclusion criteria was made separately by CC and MVE, with the knowledge of the authors or journals being assessed. The subsequent strategies associated with good-quality studies were evaluated: generation of allocation sequences and allocation concealment; blinding of investigators, participants, outcome assessors, and data analysts (yes, no, or not reported); intention-to-treat analysis (yes or no); and comprehensive follow-up. The generation of allocation sequences was considered adequate if the resulting sequences were unpredictable, such as computer-generated random numbers, and inadequate if the resulting sequences were predictable. The quality of allocation concealment was considered appropriate only if the randomization method applied unable the investigator or the participant to recognize or influence the intervention group before enrollment in the study. Allocation concealment was considered unclear when researchers claimed to have applied randomization methods but gave no description about it; it was considered inadequate when the randomization methods were unsuitable.

In relation to blinding methods, we have analyzed: doubleblind (neither patients, care providers or assessors knew which treatment was being performed), single-blind (either patients or care providers or assessors were aware of treatment), and open (all parties were aware of treatment). For studies with an intention-to-treat analysis, a positive finding on the reviewers' part meant that the authors had specifically reported undertaking this type of analysis or that our own study confirmed this finding or both. On the contrary, a negative finding either meant that authors did not report the use of intention-to-treat analysis, that we could not confirm its use on study assessment, or both. We have established the percentage of participants excluded or lost to follow-up in order to evaluate how complete was patient follow-up. Such was considered adequate if $\geq 80 \%$ of participants were included in the final analysis; if no losses to follow-up were reported we assumed that the study completeness was adequate. Furthermore, we categorized the risk of bias by the number of criteria judged inadequate in each study: low risk of bias $(\leq 1$ inadequate criterion), medium risk of bias ( $\leq 3$ inadequate criteria), and high risk of bias $(>3$ inadequate criteria).

\section{Data collection}

Two review authors (CC and MVE) assessed eligibility of studies for inclusion independently. CC and MVE initially screened the title, abstract, and key words of every report identified by the search strategy; the reviewers then retrieved the full text for potentially relevant trials and for reports whose relevance was not clear. Three of us (CC, MVE and TA) independently applied the inclusion criteria to each potentially relevant trial to ascertain its eligibility. If differences in opinion existed, they were resolved by discussion. Differences in the inclusion of trials according to their quality were resolved after consultation with the other review authors (HS and RU). Data from each study were extracted by all of the reviewers using standardized data extraction forms prepared by CC and MVE. After extraction, all data were compared to minimize the possibility of errors.

\section{Data synthesis (Statistical methods)}

The mean difference (MD) between the treatment and control groups was selected to represent the difference in continuous outcomes with a $95 \%$ confidence interval (CI). This was feasible when the mean values of the outcomes, the standard deviations of the outcomes, and the number of participants in whom the outcome was assessed in each of the 2 groups were available. If not, the analyses reported by the authors of the original articles are presented.

\section{Results}

Recently published systematic reviews and meta-analyses on this topic were identified ${ }^{(25-26,42-47)}$ and subsequently relevant references of published RCTs were found.

\section{Included studies}

All RCTs included in this systematic review were fully peerreviewed publications. 
Included RCTs analyzing the effects of LCPUFA intervention on mothers during pregnancy and/or lactation (Figure 1)

From a total of 105 existing RCTs designed to analyze the effect of LCPUFA intervention on mothers during pregnancy and/or lactation, 16 studies met the selection criteria. The included trials described 11 study populations for neurodevelopment outcome and 13 study populations assessed the growth outcome (including a total of 4524 participants), in infants and children born from supplemented pregnant and/ or fed from their supplemented mothers during lactation. The general characteristics of these RCTs Table 2 .

The time of neurodevelopment and physical growth assessment varied from birth to 7 years. The visual evaluations were performed during the age range of 0 to 5 years, and they differed from one another with regard to the vision-testing protocols and the number of vision testers.

Eighteen publications (including 11 sets of RCTs) assessed the effects of the n-3 LCPUFA supplementation during pregnancy on neurodevelopment and physical growth, on the same groups of patients and at different time points ${ }^{(48-65)}, 4$ publications ( 2 sets of RCTs) explored the effect of $n-3$ LCPUFA supplementation during pregnancy $\&$ lactation $^{(66-69)}$ and 5 publications ( 3 sets of RCTs) exclusively during lactation $^{(70-74)}$.

Six publications were focused on analyzing the supplementation to mothers during pregnancy with n-3 LCPUFA on child neurodevelopment ${ }^{(48,53-56,64)}, 5$ papers reported results on visual acuity ${ }^{(48-51,64)}$, and 14 articles examined the effect on growth as an outcome ${ }^{(48-52,54,57-64)}$.

3 articles, from the same RCT study population, explored the effect of n-3 LC-PUFA supplementation during pregnancy Elactation on the offspring neurodevelopment ${ }^{(66-68)}$ and 4 published RCTs explored the effect on infant and children growth $^{(66-69)}$.
5 publications (3 sets of RCTs) analyzed the effect of supplementing lactating mothers on their offspring neurodevelopment ${ }^{(70-74)}$, which was assessed using different tests and neurophysiologic procedures, as summarized in Table 2 .

\section{Included RCTs analyzing the effects of LCPUFA supplemented infant formulas (Figure 2)}

From 21 identified RCTs to analyze the effects of LCPUFA supplemented infant formulas on neurodevelopment and physical growth, 15 met criteria and thus were selected for inclusion in this review. The included RCTs described 15 study populations for neurodevelopment outcome and 13 study populations assessed the physical growth outcome (including $a$ total of 2061 infants and children), from birth to 2 years of age. The general characteristics of these RCTs are shown in Table 3 .

Seventeen publications (7 sets of RCTs) assessed the effects of the n-3 LCPUFA supplementation of infant formula on neurodevelopment and physical growth, in the same groups of patients and at different time points ${ }^{(32-34,75-89)}$. Another 9 RCTs which reported the complete study in a single publication were included in this review ${ }^{(90-97)}$.

Thirteen papers reported the effect of n-3 LCPUFA supplementation of infant formula on visual acuity ${ }^{(34,75,78,80,83-86,88,90,92,96-97)}, 17$ publications analyzed the effect on neurodevelopment ${ }^{(32-33,75,77-89,91-92,95,97)}$ and 13 articles reported the effect on physical growth from different $\operatorname{RCTs}^{(33,76,80-84,86,88,90-94)}$.

\section{LCPUFA supplementation during pregnancy and lactation}

Visual acuity (results are summarized in Table 4). Malcolm et al. found no significant differences in implicit times, amplitudes or parameters of the stimulus-response function in the electroretinogram in the first week of postnatal life comparing infants born to mothers receiving, from 15 weeks of

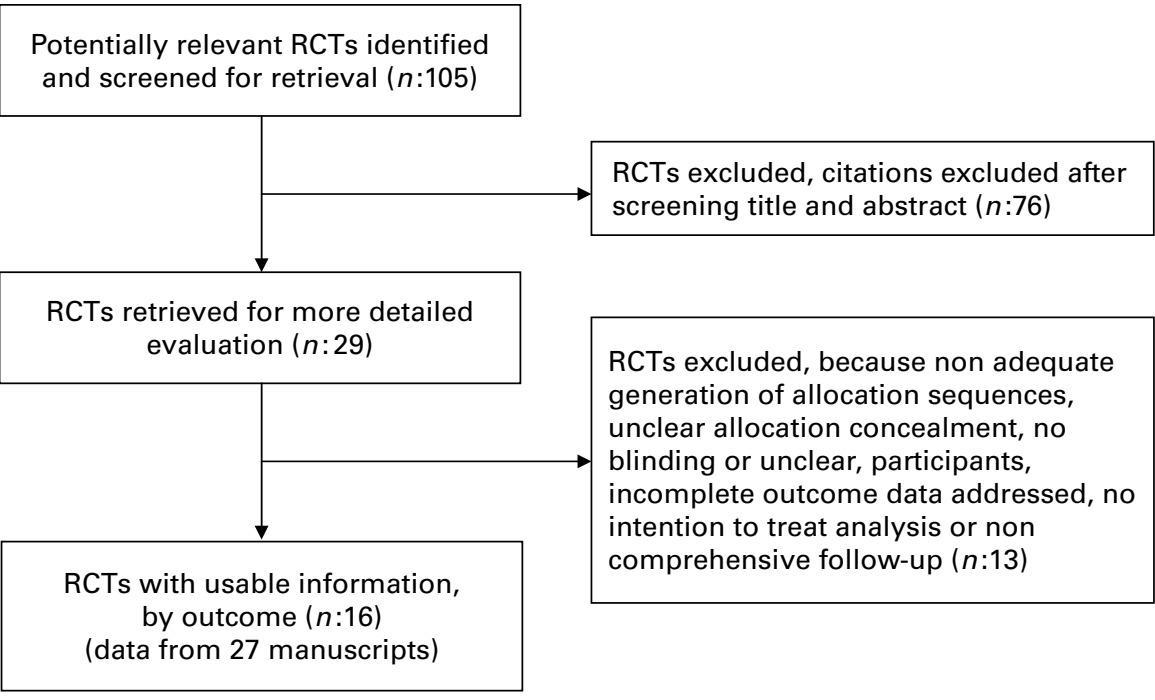

Fig. 1. Flow chart of the included RCTs analyzing the effects of LCPUFA intervention on mothers during pregnancy and/or lactation. 


\section{N British Journal of Nutrition}

Table 2. Characteristics of the included Randomized Clinical Trials (RCTs) related to analyze the effect of supplementation during pregnancy and lactation on growth and neurodevelopment

\begin{tabular}{|c|c|c|c|c|c|c|c|}
\hline \multirow[b]{2}{*}{$\mathrm{N}^{\circ}$} & \multirow{2}{*}{$\begin{array}{l}\text { Author/publication } \\
\text { year }\end{array}$} & \multirow{2}{*}{$\begin{array}{l}\text { Intervention } \\
\text { (n-3 LC-PUFA dose/day) }\end{array}$} & \multirow[b]{2}{*}{ Control } & \multirow[b]{2}{*}{ Period } & \multicolumn{2}{|c|}{$\begin{array}{c}\text { Growth parameters \& Neurological } \\
\text { examination }\end{array}$} & \multirow{2}{*}{$\begin{array}{l}\text { Growth \& Neurodevelopment } \\
\text { outcomes }\end{array}$} \\
\hline & & & & & Anthropometry/Test & Age & \\
\hline \multicolumn{8}{|c|}{ Supplementation during pregnancy } \\
\hline 1 & $\begin{array}{l}\text { Smithers et al. } \\
2011^{(65)} / \text { Australia }\end{array}$ & $\begin{array}{l}\text { Three } 500-\mathrm{mg} / \mathrm{d} \text { capsules of } \\
\text { DHA-rich FO concentrate, } \\
\text { providing: DHA: } 800 \mathrm{mg} / \mathrm{d} \\
\text { EPA: } 100 \mathrm{mg} / \mathrm{d}(n=89)\end{array}$ & $\begin{array}{l}\text { Three } 500-\mathrm{mg} / \mathrm{d} \text { vegetable oil } \\
\text { capsules without DHA } \\
(n=93)\end{array}$ & $\begin{array}{l}\text { From }<21 \\
\text { weeks of } \\
\text { pregnancy } \\
\text { until delivery }\end{array}$ & Sweep VEP & $4 \mathrm{mo}$ & $\begin{array}{l}\text { DHA supplementation in } \\
\text { women with singleton preg- } \\
\text { nancies does not enhance } \\
\text { infant visual acuity in infants } \\
\text { at } 4 \text { mo of age. }\end{array}$ \\
\hline 2 & $\begin{array}{l}{ }^{*} \text { Makrides et al. } \\
2010^{(64)} / \text { Australia }\end{array}$ & As above $(n=351)$ & As above $(n=375)$ & As above & BSID-III & $18 \mathrm{mo}$ & $\begin{array}{l}\text { No differences between } \\
\text { groups }\end{array}$ \\
\hline 3 & $\begin{array}{l}\text { Campoy et al. } \\
2011^{(56) / S p a i n,} \\
\text { Germany, } \\
\text { Hungary }\end{array}$ & $\begin{array}{l}\mathrm{FO}(500 \mathrm{mg} / \mathrm{d} \text { DHA } \\
\quad+150 \mathrm{mg} / \mathrm{d} \text { EPA })(n=37) \\
\text { or FO }+400 \mu \mathrm{g} 5-\mathrm{MTHF} \\
(n=37)\end{array}$ & $\begin{array}{l}\text { Placebo }(n=45) \text { or } 400 \mu \mathrm{g} / \mathrm{d} \\
\text { 5-MTHF }(n=35)\end{array}$ & $\begin{array}{l}\text { From } 20 \\
\text { weeks of } \\
\text { gestation } \\
\text { until delivery }\end{array}$ & $\mathrm{K}-\mathrm{ABC}$ & $6 \frac{1}{2} y$ & $\begin{array}{l}\text { No differences between } \\
\text { groups in K-ABC } \\
\text { Children whose mothers } \\
\text { had higher DHA percen- } \\
\text { tages in erythrocyte PE at } \\
\text { delivery were more likely to } \\
\text { have a MPC score of the } \\
\text { Kaufman ABC over the 50th } \\
\text { percentile at } 6.5 \mathrm{y} \text {. }\end{array}$ \\
\hline 4 & $\begin{array}{l}\text { Escolano-Margarit } \\
\text { et al. } \\
2011^{(55) / S p a i n,} \\
\text { Germany, } \\
\text { Hungary }\end{array}$ & $\begin{array}{l}\mathrm{FO}(500 \mathrm{mg} / \mathrm{d} \text { DHA } \\
\quad+150 \mathrm{mg} / \mathrm{d} \text { EPA })(n=43) \\
\text { or FO }+400 \mu \mathrm{g} 5-\mathrm{MTHF} \\
(n=37)\end{array}$ & $\begin{array}{l}\text { Placebo }(n=47) \text { or } 400 \mu \mathrm{g} / \mathrm{d} \\
\text { 5-MTHF }(n=40)\end{array}$ & $\begin{array}{l}\text { From } 20 \\
\text { weeks of } \\
\text { gestation } \\
\text { until delivery }\end{array}$ & $\begin{array}{l}\text { Hempel test } \\
\text { Touwen test }\end{array}$ & $\begin{array}{l}4 y \\
5 \frac{1}{2} y\end{array}$ & $\begin{array}{l}\text { No differences between } \\
\text { groups } \\
\text { No differences between } \\
\text { groups } \\
\text { Better neurological optimality } \\
\text { scores in children at the age } \\
\text { of } 5.5 \text { y with increasing } \\
\text { DHA levels in cord blood at } \\
\text { delivery }\end{array}$ \\
\hline 5 & $\begin{array}{l}\text { Courville et al. } \\
2011^{(59)} / \text { USA }\end{array}$ & $\begin{array}{l}\text { DHA cereal-based } 5 \text { bars/ } \\
\text { week DHA: } 300 \mathrm{mg} \\
\text { (EPA:DHA = 1:8) Mean } \\
\text { intake: } 214 \mathrm{mg} \text { DHA/d } \\
\text { (n:22) }\end{array}$ & $\begin{array}{l}\text { Placebo (n:25) Maize oil } \\
\quad(\mathrm{n}: 22)\end{array}$ & $\begin{array}{l}\text { From } 20-24 \\
\text { weeks until } \\
\text { delivery }\end{array}$ & Weight, Length, $\mathrm{HC}$ & At birth & $\begin{array}{l}\text { No statistical differences } \\
\text { between supplemented } \\
\text { groups }\end{array}$ \\
\hline 6 & $\begin{array}{l}\text { Stein et al. } \\
2011^{(62)} / \text { Mexico }\end{array}$ & $\begin{array}{l}\text { Algal oil capsules DHA: } \\
400 \mathrm{mg} / \text { day } \\
\text { (Median DHA intake: } \\
55 \mathrm{mg} / \mathrm{d})(n=370)\end{array}$ & Placebo $(n=369)$ & $\begin{array}{l}\text { From } 18-22 \\
\text { weeks until } \\
\text { delivery }\end{array}$ & Weight, Length, HC & $18 \mathrm{mo}$ & $\begin{array}{l}\text { Heterogeneity of associations } \\
\text { by maternal gravidity for } \\
\text { weight, length and head cir- } \\
\text { cumference. (n:739; } 76 \% \text { of } \\
\text { the birth cohort) } \\
\text { Offspring of supplemented pri- } \\
\text { migravide mothers had } \\
\text { higher length than controls. }\end{array}$ \\
\hline 7 & $\begin{array}{l}\text { Ramakrishnan et al. } \\
2010^{(58)} / \text { Mexico }\end{array}$ & $\begin{array}{l}\text { Algal oil capsules DHA: } \\
400 \mathrm{mg} / \text { day (Median DHA } \\
\text { intake: } 55 \mathrm{mg} / \mathrm{d})(\mathrm{n}: 540)\end{array}$ & Placebo (n:554) & $\begin{array}{l}\text { From } 18-22 \\
\text { weeks until } \\
\text { delivery }\end{array}$ & Weight, Length, HC & At birth & $\begin{array}{l}\text { Offspring of supplemented pri- } \\
\text { migravide mothers were } \\
\text { heavier ( } \mathrm{n}: 370) \text { and had lar- } \\
\text { ger head circumferences } \\
\text { than controls }(\mathrm{n}: 603) \text {. }\end{array}$ \\
\hline
\end{tabular}




\section{N British Journal of Nutrition}

$\begin{array}{ll}\mathrm{N}^{\circ} & \text { Author/publication } \\ & \text { year }\end{array}$

8 Dunstan et al. $2008^{(48)} /$ Australia Intervention (n-3 LC-PUFA dose/day)

Fish oil capsules: DHA $2 \cdot 2 \mathrm{~g} / \mathrm{d}+$ EPA: $1.1 \mathrm{~g} / \mathrm{d}$ $(n=52)$

\section{acid}

$.7 \mathrm{~g} / \mathrm{d}(n=46)$

Growth parameters \& Neurologica examination

$\begin{array}{ll}\text { Anthropometry/Test } & \text { Age } \\ \text { Weight and Length } & \text { At birth } \\ \text { GMDS } & 2 \frac{1}{2} y \\ \text { PPVT } & \end{array}$

outcomes

No differences in growth

between groups

20 weeks GMDS

Soybean and corn oil capsules: LA $0.53 \mathrm{~g}, \mathrm{ALA}$

$0.08 \mathrm{~g} / \mathrm{d}(n=68)$

Crythecodinium cohnii (DHA

$$
\approx 0.4 \mathrm{~g} / \mathrm{d} ; n=67 \text { ) }
$$

10 Judge et al. $2007 \mathrm{~b}^{(53)} / \mathrm{USA}$

\section{$\mathrm{DHA}$$$
\text { bars }
$$

(300 mg as low EPA fish oil: EPA:DHA 1:8); $\approx$ DHA

$214 \mathrm{mg} / \mathrm{wk})(n=16)$

11 Judge et al. $2007 \mathrm{a}^{(52)} / \mathrm{USA}$

$$
\text { As above }(n=14)
$$

Fish oil capsules containing DHA $1.2 \mathrm{~g} / \mathrm{d}+$ EPA $1.8 \mathrm{~g} / \mathrm{d}$ $(n=200)$

$2006^{(54)}$
desh

Fat $(2 \mathrm{~g} / \mathrm{d}) ; 200 \mathrm{mg}$

$\mathrm{DHA} / \mathrm{d}+40 \mathrm{mg} \mathrm{EPA} / \mathrm{d}$

$2004^{(63)} /$ Spain
As above $(n=15)$

Soy oil capsules:

LA: $2.25 \mathrm{~g} / \mathrm{d}$

LNA: $0.27 \mathrm{~g} / \mathrm{d}(n=200)$
Placebo

Cereal-based Placebo bar
with Corn oil $(n=14)$
As above $(n=15)$
Soy oil capsules:
LA: $2 \cdot 25 \mathrm{~g} / \mathrm{d}$
LNA: $0.27 \mathrm{~g} / \mathrm{d}(n=200)$
Placebo

As

gestation PPVT

until delivery $\mathrm{CBCL}$

From 14-16

weeks ges-

Weight and Length

delivery$$
\text { VEPC }
$$

Teller acuity Card

At birth

$60 \pm 3$ days

GMDS: supplemented group

(S): higher eye hand coordnation. No differences for

mean general quotient and other subscales.

S: Significant positive corre-

lation between eye and

hand coordination and $n-3$

LC-PUFA in cord blood.

$S$ : Inverse correlation

between eye and hand

coordination and performance

score with $\mathrm{AA}$ in cord blood.

PPVT: No differences; $\mathrm{CBCL}$ :

No differences.

No differences in growth

between groups

No differences between

groups; Differences

between boys and girls;

ncreased risk of low visual

acuity among 60-d-old

infants of mothers following

their usual diet compared

with infants of DHA sup-

plemented women.

Problem solving: S Group bet-

ter performance.

Fagan Test of Infant Intelli-

gence: No differences (rec-

ognition memory abilities)

No differences in growth

between groups

Better Visual Acuity at $4 \mathrm{~m}$, no

differences at 6 mo

From 25

weeks ges-

Weight \& Length

$4 m \& 6 m$

No differences between

$\begin{array}{ll}\text { At birth } & \text { No difference } \\ 10 \mathrm{~m} & \text { groups }\end{array}$

delivery

rom weeks

$27-28$ of

delivery
Psychosocial stimulation at

home (HOME)

Weight

At birth 
Table 2. Continued

\begin{tabular}{|c|c|c|c|c|c|c|c|}
\hline \multirow[b]{2}{*}{$\mathrm{N}^{\circ}$} & \multirow{2}{*}{$\begin{array}{l}\text { Author/publication } \\
\text { year }\end{array}$} & \multirow{2}{*}{$\begin{array}{l}\text { Intervention } \\
\text { (n-3 LC-PUFA dose/day) }\end{array}$} & \multirow[b]{2}{*}{ Control } & \multirow[b]{2}{*}{ Period } & \multicolumn{2}{|c|}{$\begin{array}{c}\text { Growth parameters \& Neurological } \\
\text { examination }\end{array}$} & \multirow{2}{*}{$\begin{array}{l}\text { Growth \& Neurodevelopment } \\
\text { outcomes }\end{array}$} \\
\hline & & & & & Anthropometry/Test & Age & \\
\hline 14 & $\begin{array}{l}\text { Smuts et al. } \\
2003 \mathrm{a}^{(60)} / \text { USA }\end{array}$ & $\begin{array}{l}\text { High-DHA eggs: DHA: } \\
135 \mathrm{mg} / \mathrm{egg} ; \mathrm{mean} \text { intake } \\
=206 \pm 112 \mathrm{mg} / \mathrm{DHA} / \mathrm{d} \\
(n=27)\end{array}$ & $\begin{array}{l}\text { Ordinary eggs }(n=25) \text { : DHA: } \\
18 \mathrm{mg} / \mathrm{egg} \text {; mean intake } \\
=23 \pm 9 \mathrm{mg} / \mathrm{d} \text {; Low-egg } \\
\text { intake group }(n=26) \text { mean } \\
\text { DHA intake }=7 \pm 9 \mathrm{mg} / \mathrm{d}\end{array}$ & $\begin{array}{l}\text { Possibly 3rd } \\
\text { trimester (no } \\
\text { information } \\
\text { provided); } \\
\text { mean: } \approx 13 \\
\text { wk }\end{array}$ & Weight, Length, $\mathrm{HC}$ & At birth & $\begin{array}{l}\text { No differences between } \\
\text { groups }\end{array}$ \\
\hline 15 & $\begin{array}{l}\text { Smuts et al. } \\
2003 b^{(61)} / \text { USA }\end{array}$ & $\begin{array}{l}\text { High-DHA eggs ( } n=176): \\
\text { DHA: } 133 \mathrm{mg} / \mathrm{egg} \text {; mean } \\
\text { intake } 7.2 \pm 3.4 \mathrm{eggs} / \mathrm{wk} \\
=137 \pm 65 \mathrm{mg} / \mathrm{DHA} / \mathrm{d}\end{array}$ & $\begin{array}{l}\text { Ordinary eggs }(n=174) \text { : } \\
\text { DHA: } 33 \mathrm{mg} \mathrm{DHA} / \mathrm{egg} ; \\
\text { intake }=7 \cdot 3 \pm 3 \cdot 4 \mathrm{eggs} / \mathrm{wk} \\
=34 \pm 16 \mathrm{mg} \mathrm{DHA} / \mathrm{d}\end{array}$ & $\begin{array}{l}\text { From weeks } \\
24-28 \text { of } \\
\text { gestation to } \\
\text { delivery }\end{array}$ & Weight, Length, $\mathrm{HC}$ & At birth & $\begin{array}{l}\text { DHA intake correlated with } \\
\text { birth weight }\end{array}$ \\
\hline 16 & $\begin{array}{l}\text { Malcolm et al. } \\
2003 b^{(49)} / U K\end{array}$ & $\begin{array}{l}\text { Fish oil capsules: } 0.1 \mathrm{~g} \text { of } \\
\text { DHA in } 0.323 \mathrm{~g} \text { oil per cap- } \\
\text { sule DHA } 0.2 \mathrm{~g} / \mathrm{d} \text { (EPA:DHA } \\
1: 6)(n=50)\end{array}$ & $\begin{array}{l}\text { Sunflower oil capsules } \\
\text { 0.323 g/d ( } 81 \% \text { oleic acid) } \\
(n=50)\end{array}$ & $\begin{array}{l}\text { From } 15 \\
\text { weeks of } \\
\text { gestation } \\
\text { until delivery }\end{array}$ & $\begin{array}{l}\text { Visual assessment } \\
\text { Transient flash VEP } \\
\text { Pattern-reversal stimuli VEP }\end{array}$ & $\begin{array}{l}1,50 \& 66 \\
\text { weeks } \\
\text { post-con- } \\
\text { ceptional } \\
\text { age }\end{array}$ & $\begin{array}{l}\text { No differences between } \\
\text { groups } \\
\text { Peak latency of the P100 was } \\
4.6 \mathrm{~ms} \text { shorter for infants } \\
\text { with } 1 \% \text { higher DHA status } \\
\text { in umbilical cord. } \\
\text { Association between DHA sta- } \\
\text { tus of infants at term and } \\
\text { early postnatal pattern- } \\
\text { reversal VEP }\end{array}$ \\
\hline 17 & $\begin{array}{l}\text { Malcolm et al. } \\
2003 a^{(50)} / \text { UK }\end{array}$ & As above & As above & As above & $\begin{array}{l}\text { Weight, Length \& HC } \\
\text { VEP } \\
\text { Scotopic Electroretinography }\end{array}$ & $\begin{array}{l}\text { At birth } \\
1 \text { week of } \\
\text { life }\end{array}$ & $\begin{array}{l}\text { No differences in growth } \\
\text { between groups } \\
\text { No differences between } \\
\text { groups. } \\
\text { Infants in the highest quartile } \\
\text { for cord blood DHA had } \\
\text { higher retinal sensitivity } \\
\text { compared with infants in the } \\
\text { lowest quartile. }\end{array}$ \\
\hline 18 & $\begin{array}{l}\text { Olsen et al. } \\
1992^{(57)} / \text { Denmark }\end{array}$ & $\begin{array}{l}\text { Fish oil }(4 \mathrm{~g} / \mathrm{d}) \text { : DHA: } \\
\quad 920 \mathrm{mg} / \mathrm{d}+\text { EPA: } \\
1280 \mathrm{mg} / \mathrm{d} \text { Vit E: } 2 \mathrm{mg} / \mathrm{d} \\
\approx 2.7 \mathrm{~g} \mathrm{n}-3 \text { PUFA } / \mathrm{d}\end{array}$ & $\begin{array}{l}\text { Olive oil }(4 \mathrm{~g} / \mathrm{d}) \text { or no oil } \\
\text { supplement }\end{array}$ & $\begin{array}{l}\text { From week } 30 \\
\text { of gestation } \\
\text { until delivery }\end{array}$ & $\begin{array}{l}\text { Weight } \\
\text { Length }\end{array}$ & at birth & $\begin{array}{l}\text { No statistical differences } \\
\text { between groups }\end{array}$ \\
\hline \multicolumn{8}{|c|}{ Supplementation during pregnancy and lactation } \\
\hline 1 & $\begin{array}{l}\text { Helland et al. } \\
2008^{(68)} / \text { Norway }\end{array}$ & $\begin{array}{l}\text { Cod liver oil Containing DHA: } \\
1 \cdot 183 \mathrm{~g} / \mathrm{d}+\text { EPA: } \\
0,803 \mathrm{~g} / \mathrm{d}+\text { vitamins A, D } \\
\text { and } \mathrm{E}(n=82)\end{array}$ & $\begin{array}{l}\text { Corn oil containing LA: } \\
4.747 \mathrm{~g} / \mathrm{d}+\mathrm{ALA}: \\
0,092 \mathrm{~g} / \mathrm{d}+\text { vitamins } \mathrm{A}, \mathrm{D} \\
\text { and } \mathrm{E}(n=61)\end{array}$ & $\begin{array}{l}\text { From } 17-19 \\
\text { weeks of } \\
\text { gestation } \\
\text { until } 3 \mathrm{~m} \\
\text { after delivery }\end{array}$ & $\begin{array}{l}\text { Weight, Height, BMI } \\
\text { K-ABC }\end{array}$ & $7 y$ & $\begin{array}{l}\text { No significant differences in } \\
\text { growth } \\
\text { No significant differences in } \\
\text { scores on the K-ABC } \\
\text { between groups. }\end{array}$ \\
\hline 2 & $\begin{array}{l}\text { Lucia et al. } \\
\qquad 2007^{(69)} / \text { Germany }\end{array}$ & $\begin{array}{l}\text { Supplement consisting Fish } \\
\text { oil: DHA } 200 \mathrm{mg}+\text { Vitamins } \\
\text { and minerals }+4.5 \mathrm{~g} \text { FOS } \\
(n=43)\end{array}$ & $\begin{array}{l}\text { ( } n=74) \text { Basic supplement } \\
\text { containing: Vitamins \& min- } \\
\text { erals or Vitamins \& minerals } \\
\& 4.5 \mathrm{~g} \mathrm{FOS}\end{array}$ & $\begin{array}{l}\text { From } 21 \text { st } \\
\text { week of ges- } \\
\text { tation until } 3 \\
\text { mo after } \\
\text { delivery }\end{array}$ & Weight, Length, HC & $1,3,21 \mathrm{mo}$ & $\begin{array}{l}\text { Significant lower BMI and birth } \\
\text { weight in babies from DHA } \\
\text { supplemented mothers, at } \\
1,3 \text { and } 21 \text { mo }\end{array}$ \\
\hline
\end{tabular}




\section{N British Journal of Nutrition}

\begin{tabular}{|c|c|c|c|c|c|c|}
\hline \multirow[b]{2}{*}{$\mathrm{N}^{\circ}$} & \multirow{2}{*}{$\begin{array}{l}\text { Author/publication } \\
\text { year }\end{array}$} & \multirow{2}{*}{$\begin{array}{l}\text { Intervention } \\
\text { (n-3 LC-PUFA dose/day) }\end{array}$} & \multirow[b]{2}{*}{ Control } & \multirow[b]{2}{*}{ Period } & \multicolumn{2}{|c|}{ examination } \\
\hline & & & & & Anthropometry/Test & Age \\
\hline 3 & $\begin{array}{l}\text { Helland et al. } \\
2003^{(67)} / \text { Norway }\end{array}$ & As above $(n=48)$ & As above $(n=52)$ & As above & $\mathrm{K}-\mathrm{ABC}$ & $4 y$ \\
\hline 4 & $\begin{array}{l}\text { Helland et al. } \\
2001^{(66)} / \text { Norway }\end{array}$ & As above $(n=175)$ & As above $(n=166)$ & As above & $\begin{array}{l}\text { Weight, Length, HC } \\
\text { EEG } \\
\text { Fagan Test of Infant Intel- } \\
\text { ligence }\end{array}$ & $\begin{array}{l}\text { At birth } \\
2 \mathrm{~d}, 3 \mathrm{mo} \\
6 \mathrm{mo}, 9 \mathrm{mo}\end{array}$ \\
\hline
\end{tabular}

Growth \& Neurodevelopment outcomes

Higher Mental Processing

Composite scores of the $\mathrm{K}$ $A B C$ at $4 y$ in children from DHA and EPA sup-

plemented mothers. MPC 4 years correlated with maternal intake of DHA and EPA.

No differences in growth

between groups

No differences in EEG scores or Fagan scores.

Neonates with mature EEG $(N=70)$ had a higher concentration of DHA in umbilical plasma phospholipids than neonates with immature EEG $(N=51)$ on the second day of life.

\section{Supplementation during lactation}

1 Cheatham, et al. $2011^{(73)} /$ Denmark

Microencapsulated Fish oil added to müsli bars or to

homemade cookies or as capsules containing n-3 LC PUFA $1.5 \mathrm{~g} / \mathrm{d}$ (DHA $0.9 \mathrm{~g} / \mathrm{d}$ ); low content of EPA $(n=36)$

2 Jensen et al. $2010^{(74)} /$ USA

$$
\begin{aligned}
& \text { Algal oil capsules } \\
& \quad(\approx 200 \mathrm{mg} / \mathrm{d} \text { DHA }) \\
& (n=114)
\end{aligned}
$$

$$
\begin{aligned}
& 56 \cdot 3 \%, \text { ALA: } 3.9 \% \\
& (n=113)
\end{aligned}
$$

Vegetable oil capsules: $\mathrm{LA}$

\section{For 4 month after delivery}

Gross and fine motor function; Perceptual/visual-moto function; Attention, Executive Function; Verbal skills; Sweep VEP, transient VE and Bayley-Lovie cards

Teller Acuity Card

Sweep VEP

BSID
Negative effect on pro-social behavior score in boys Speed of processing scores were predicted by maternal n-3 LCPUFA scores (negative relation) and maternal education (positive relation) Stroop scores: working memory and inhibitory control erythrocyte DHA status at 4 months (negative relation). mo differences in visu

tion between groups tion between groups Children whose mothers
received DHA versus placebo performed significantly better on the Sustained Attention Subscale of the Leiter International Performance Scale.

4 and $8 \mathrm{~m}$ 12 and $30 \mathrm{~m}$

amplitude in babies

rom DHA supplemented mothers

Higher PDI at $30 \mathrm{mo}$ of age in children from DHA supplemented mothers. 
Table 2. Continued

\begin{tabular}{|c|c|c|c|c|c|c|c|}
\hline \multirow[b]{2}{*}{$\mathrm{N}^{\circ}$} & \multirow{2}{*}{$\begin{array}{l}\text { Author/publication } \\
\text { year }\end{array}$} & \multirow{2}{*}{$\begin{array}{l}\text { Intervention } \\
\text { (n-3 LC-PUFA dose/day) }\end{array}$} & \multirow[b]{2}{*}{ Control } & \multirow[b]{2}{*}{ Period } & \multicolumn{2}{|c|}{$\begin{array}{c}\text { Growth parameters \& Neurological } \\
\text { examination }\end{array}$} & \multirow{2}{*}{$\begin{array}{l}\text { Growth \& Neurodevelopment } \\
\text { outcomes }\end{array}$} \\
\hline & & & & & Anthropometry/Test & Age & \\
\hline 4 & $\begin{array}{l}\text { Lauritzen et al. } \\
2005^{(72)} / \text { Denmark }\end{array}$ & $\begin{array}{l}\text { Microencapsulated Fish oil } \\
\text { (müsli bars or homemade } \\
\text { cookies or as capsules) } \\
\text { containing } \mathrm{n}-3 \mathrm{LC}-\mathrm{PUFA} \\
1.5 \mathrm{~g} / \mathrm{d}(\mathrm{DHA} \approx 0.9 \mathrm{~g} / \mathrm{d}) ; \\
\text { low content of EPA }(n=48)\end{array}$ & $\begin{array}{l}\text { Microencapsulated } \\
\text { Olive oil added to müsli bars } \\
\text { or to homemade cookies or } \\
\text { as capsules }(n=38)\end{array}$ & $\begin{array}{l}\text { For } 4 \text { months } \\
\text { after delivery }\end{array}$ & $\begin{array}{l}\text { Problem solving ability } \\
\text { Infant linguistic develop- } \\
\text { ment }\{\text { MacArthur CDI forms } \\
\text { for infant }(8-16 \mathrm{mo}) \& \text { tod- } \\
\text { dler }(16-30 \mathrm{mo})\}\end{array}$ & $\begin{array}{l}9 \mathrm{~m} \\
1 \text { and } 2 y\end{array}$ & $\begin{array}{l}\text { No significant differences on } \\
\text { problem solving between } \\
\text { groups. } \\
\text { Passive vocabulary was lower } \\
\text { in children aged } 1 \text { of the FO } \\
\text { compared to OO group. } \\
\text { Word comprehension at } 1 \text { y } \\
\text { was inversely associated } \\
\text { with erythrocyte-DHA at } 4 \\
\text { mo. } \\
\text { Small effect of DHA levels in } \\
\text { breast-milk on early } \\
\text { language development. }\end{array}$ \\
\hline 5 & $\begin{array}{l}\text { Lauritzen et al. } \\
2004^{(71)} / \text { Denmark }\end{array}$ & As above $(n=53)$ & As above $(n=44)$ & As above & $\begin{array}{l}\text { Infant visual acuity (measured } \\
\text { by Sweep VEP) }\end{array}$ & 2 and $4 \mathrm{mo}$ & $\begin{array}{l}\text { No differences in the Sweep } \\
\text { VEP patterns between } \\
\text { groups. } \\
\text { Higher red blood cell levels of } \\
\text { n-3 LCPUFA was associ- } \\
\text { ated to better visual acuity } \\
\text { at } 4 \text { mo of age }\end{array}$ \\
\hline
\end{tabular}

FO: Fish Oil; OO:Olive oil; HC: Head circumference; LCPUFAs: Long chain polyunsaturated fatty acids; LA: Linoleic acid; ALA: $\alpha$-linolenic acid; DHA: Docosahexaenoic acid; EPA: Eicosapentaenoic acid; GMDS: Griffiths Mental Development Scales; PPVT: Peabody Picture Vocabulary Test; K-ABC: Kaufman ABC; MPC: Mental Processing Composite; CBCL: Child Behavior Checklist; BSID: Bayley Scales of Infant Development; PDI: Psychomotor
Development Index; MDI: Mental Development Index; MacArthur: CDI: Communicative Development Inventory; VEP: Visual evoked potentials; EEG: Electroencephalography. *Included term and preterm infants. 


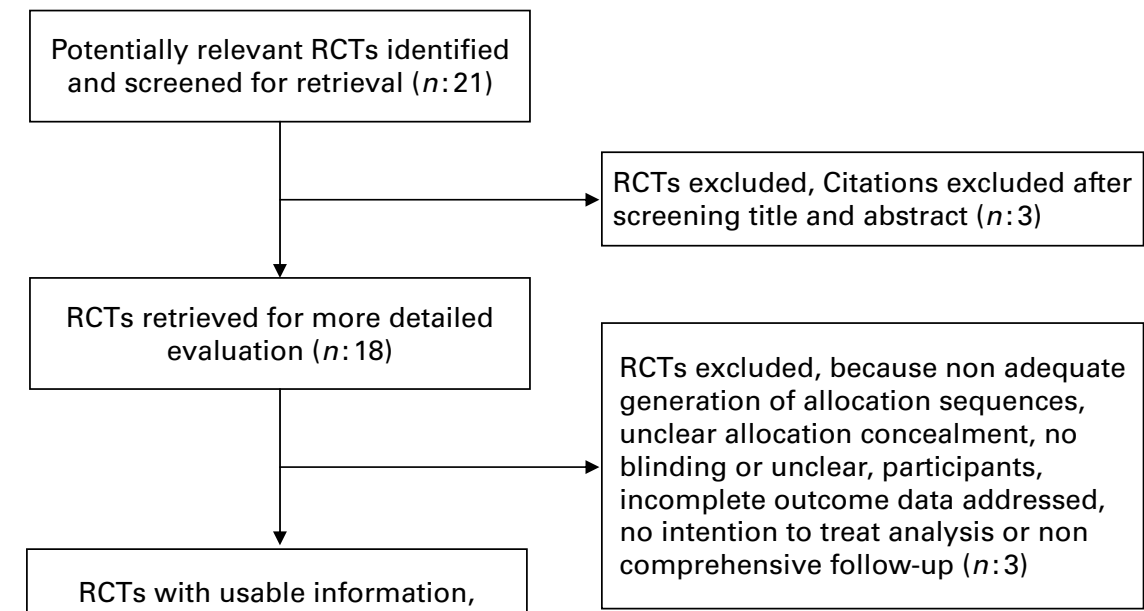

Fig. 2. Flow chart of the included RCTs analyzing the effects of LCPUFA supplemented infant formulas on visual acuity, neurodevelopment and growth

pregnancy til delivery, $200 \mathrm{mg}$ of DHA/day supplements during pregnancy and those receiving placebo ${ }^{(49-50)}$. There were also no differences in the measures of transient flash VEP waveform at birth and at the ages of 50 and 66 weeks postconceptional age (PCA); However, positive associations were found between infants' DHA status at birth and the sensitivity and maturity of the rod photoreceptors responses at birth $^{(49)}$, as well as, with the maturity of the pattern-reversal VEP at the ages of 50 and 66 weeks ${ }^{(50)}$.

Innis et al. found no significant differences in the Teller acuity cards at the age of 60 days PCA between infants born from mothers receiving DHA supplements during pregnancy and those who didn't. However, infants in the placebo group were more likely to have a lower visual acuity than those born to DHA-supplemented mothers ${ }^{(51)}$. Judge et al. ${ }^{(52)}$ showed significant main effects for visual acuity at 4 months of age in those infants whose mothers were supplemented during pregnancy (DHA group), and no differences at 6 months of age; however, in the regression analysis the authors show better visual acuity in the offspring of the DHA supplemented group mothers at 4 months. Smithers et $a l .{ }^{(65)}$ reported results from the DOMInO trial showing that in those infants whose mothers were supplemented during pregnancy with $800 \mathrm{mg} / \mathrm{d}$ of DHA $+100 \mathrm{mg}$ of EPA, and were fed only breast milk, the VEP acuity at 4 mo of age was not different compared to the control group. Lauritzen et al. reported no significant differences in Sweep VEP at 2 and 4 mo in babies whose mothers received fish oil supplementation during lactation; however, higher red blood cell n-3 LCPUFA content were associated with better visual acuity at 4 mo of age ${ }^{(71)}$.

Studies based on lactating mothers' supplementation with n-3 LCPUFA have shown also some controversial results. Jensen et al. demonstrated that supplementation to mothers during lactation with $200 \mathrm{mg} / \mathrm{d}$ of DHA determines lower amplitude in the Sweep VEP in their infants at 4 \& 8 months ${ }^{(70)}$, but these differences in visual function (Sweep
VEP, transient VEP and Bayley-Lovie cards) were not confirmed at 5 years $^{(74)}$.

Neurodevelopment. The main results are shown in Table 5. Four studies assessed neurological outcome in the first 2 years of life after n-3 LCPUFA supplementation in pregnancy, none reported significant effects on performance in neurologic tests in the supplemented group; two reported no differences between the supplemented and control group performance in the Fagan Test of Infant Intelligence (FTII) at 6 and 9 months of age ${ }^{(53,66)}$ and three reported no differences in the BSID at $10^{\text {th }}$ and $18^{\text {th }}$ months ${ }^{(54,70,64)}$. Helland et $a{ }^{(66)}$ reported no differences in electroencephalogram (EEG) maturity at 2 days and 3 months after birth between groups, but observed that higher EPA and DHA levels were associated with more mature EEG patterns. Judge et al. ${ }^{(53)}$ reported a positive effect of supplementation on the 2 step problem solving test at $9^{\text {th }}$ months post birth. Dunstan et al. reported better eye and hand coordination in the Griffiths Mental Development Scales (GMDS) in the supplemented group at 2.5 years, a significant positive association with $n-3$ LCPUFA and an inverse correlation with AA in cord blood $^{(48)}$. Based on our evaluation of the data to date, 3 trials have reported long term effects of supplementation to date. Helland et al. reported better performance in the K-ABC mental development test in the supplemented group compared to control at 4 years of age, but this effect was not observed when IQ was measured at 7 years. The authors also report a significant positive correlation between IQ at 4 years and DHA levels in infant plasma at $4^{\text {th }}$ weeks of life as well as an association between maternal DHA levels at 35 week gestation and IQ in the children at 7 years ${ }^{(67-68)}$. The NUHEAL trial reported no differences in neurological outcome of children assessed with Hempel (4 years) and Touwen examinations ( 5.5 years) between children born to mothers receiving fish oil supplements and those who didn't; but, the authors also demonstrated better neurological scores in children at 5.5 yrs with increasing higher DHA levels in cord 
Table 3. Characteristics of the included Randomized Clinical Trials (RCTs) related to analyze the effect of infant formula supplementation on growth and neurodevelopment in term infants

\begin{tabular}{|c|c|c|c|c|c|c|c|}
\hline \multirow[b]{2}{*}{$\mathrm{N}^{\circ}$} & \multirow[b]{2}{*}{$\begin{array}{l}\text { Author/publication } \\
\text { year/country }\end{array}$} & \multirow[b]{2}{*}{$\begin{array}{l}\text { Intervention } \\
\text { (n-3 LC-PUFA dose/day) }\end{array}$} & \multirow[b]{2}{*}{ Control } & \multirow[b]{2}{*}{ Period } & \multicolumn{2}{|c|}{ Growth \& Neurological examination } & \multirow[b]{2}{*}{$\begin{array}{l}\text { Growth \& Neurodevelopment } \\
\text { outcomes }\end{array}$} \\
\hline & & & & & $\begin{array}{l}\text { Anthropometry and } \\
\text { Neurological Test }\end{array}$ & Age & \\
\hline 1 & $\begin{array}{l}\text { Drover et al. } \\
2011^{(75)} / \text { USA }\end{array}$ & $\begin{array}{l}\text { Infant formula supplemented with } \\
\text { DHA + AA from single-cell } \\
\text { algal (Crypthecodinium cohnii) } \\
\text { \& fungal (Mortirella alpina) oils, } \\
\text { at different dosis: DHA: } 0.32 \% \\
\text { (Enfamil LIPIL }(\mathbb{R})(n=29), \\
0.64 \%(n=32) \text { or } 0.96 \% \\
\text { (n=28)+ AA: 0.64 \% LA: } \\
16.9 \%-17.5 \% \text { ALA: } 1.61 \%- \\
1.68 \%\end{array}$ & $\begin{array}{l}\text { Infant formula with DHA: } \\
0 \% ® \text { AA: } 0 \% \text { (Enfamil } \\
\text { with Iron) }(n=28) \text { LA: } \\
16.9 \%-17.5 \% \text { ALA: } \\
1.61 \%-1.68 \%\end{array}$ & $\begin{array}{l}\text { First } 12 \text { mo of } \\
\text { life, sole } \\
\text { source of } \\
\text { nutrition until } \\
\approx 4 \text { mo of } \\
\text { age }\end{array}$ & BSID II & $18 \mathrm{mo}$ & $\begin{array}{l}\text { No significant differences in MDI, } \\
\text { PDI or BRS between the sup- } \\
\text { plemented groups. } \\
\text { MDI scores of DHA-supplemented } \\
\text { children were higher than those } \\
\text { who did not received DHA sup- } \\
\text { plementation (pooling those sup- } \\
\text { plemented with DHA). }\end{array}$ \\
\hline 2 & $\begin{array}{l}\text { Birch EE et al. } \\
2010^{(76)} / \text { USA }\end{array}$ & $\begin{array}{l}\text { Infant formula supplemented with } \\
\text { DHA + AA from single-cell } \\
\text { algal (Crypthecodinium cohnii) } \\
\text { \& fungal (Mortirella alpina) oils, } \\
\text { at different dosis: DHA: } 0.32 \% \\
\text { (Enfamil LIPIL }(\mathbb{R})(n=83), \\
0.64 \%(n=85) \text { or } 0.96 \% \\
(n=88)+\text { AA: } 0.64 \% \text { LA: } \\
16.9 \%-17.5 \% \text { ALA: } 1.61 \%- \\
1.68 \%\end{array}$ & $\begin{array}{l}\text { Infant formula with DHA: } \\
0 \% \AA \text { AA: } 0 \% \text { (Enfamil } \\
\text { with Iron) }(n=86) \text { LA: } \\
16.9 \%-17.5 \% \text { ALA: } \\
1.61 \%-1.68 \%\end{array}$ & $\begin{array}{l}\text { First } 12 \text { mo of } \\
\text { life, sole } \\
\text { source of } \\
\text { nutrition until } \\
\approx 4 \text { mo of } \\
\text { age }\end{array}$ & $\begin{array}{l}\text { Weight, Length, } \\
\text { weight/length and } \\
\text { HC } \\
\text { Sweep VEP Acuity }\end{array}$ & $\begin{array}{l}1.5,4,6,9 \\
12 \mathrm{mo}\end{array}$ & $\begin{array}{l}\text { No differences in physical growth } \\
\text { between groups } \\
\text { Infants fed control formula had sig- } \\
\text { nificantly poorer visual evoked } \\
\text { potential visual acuity at } 12 \text { mo of } \\
\text { age than did infants who received } \\
\text { any of the DHA-supplemented } \\
\text { formulas }(0.32 \% \text { to } 0.64 \%) \\
(P<0.001) \text {. }\end{array}$ \\
\hline 3 & $\begin{array}{l}\text { De Jong C, et al. } \\
2010^{(77)} / \text { The Neth- } \\
\text { erlands }\end{array}$ & $\begin{array}{l}\text { Infant formula supplemented } \\
\text { with: DHA: } 0.30 \%+\text { AA: } \\
0.45 \%(n=146)\end{array}$ & $\begin{array}{l}\text { Standard Infant formula } \\
\quad(n=169) \\
\text { Breastfed reference group } \\
\quad(n=160)\end{array}$ & $\begin{array}{l}\text { From birth to } 2 \\
\text { mo of life }\end{array}$ & Touwen & $9 \mathrm{y}$ & $\begin{array}{l}\text { No significant differences in neuro- } \\
\text { logical function between groups. } \\
\text { Breast-fed children have a } \\
\text { slightly better neurodevelopmen- } \\
\text { tal outcome than formula fed. }\end{array}$ \\
\hline 4 & $\begin{array}{l}\text { Birch EE, et al. } \\
2007^{(78)} / \text { USA }\end{array}$ & $\begin{array}{l}\text { Infant formula supplemented } \\
\text { with(microalgal/microfungal } \\
\text { LCP): DHA: } 0.36 \%+\text { AA: } \\
0 \cdot 72 \%(n=17) \\
\text { Or only with: DHA: } 0.36 \% \\
(n=16)\end{array}$ & $\begin{array}{l}\text { Standard Infant formula } \\
\quad(n=19) \\
\text { Breastfed reference group } \\
\quad(n=32)\end{array}$ & $\begin{array}{l}\text { From birth to } 2 \\
\text { mo of life }\end{array}$ & $\begin{array}{l}\text { HOTV visual acuity } \\
\text { Amblyopia Treatment } \\
\text { Study (ATS); Elec- } \\
\text { tronic Visual Acuity } \\
\text { (EVA) } \\
\text { Wechsler preschool \& } \\
\text { primary scale of } \\
\text { Intelligence; and } \\
\text { WPPSI-R }\end{array}$ & $4 \mathrm{y}$ & $\begin{array}{l}\text { No differences in visual acuity } \\
\text { between DHA and DHA + AA- } \\
\text { supplemented groups compared } \\
\text { to breast fed infants. Control } \\
\text { group showed poorer visual } \\
\text { acuity than breast-fed one. } \\
\text { IQ maturation is similar in the sup- } \\
\text { plemented and control groups to } \\
\text { that of breast-fed infants. }\end{array}$ \\
\hline 5 & $\begin{array}{l}\text { Bouwstra } \mathrm{H} \text { et al. } \\
2005^{(79} / \text { Nether- } \\
\text { lands }\end{array}$ & $\begin{array}{l}\text { Infant formula supplemented } \\
\text { with: DHA: } 0.30 \%+\text { AA: } \\
0.45 \%(n=146)\end{array}$ & $\begin{array}{l}\text { Standard Infant formula } \\
\quad(n=169) \\
\text { Breastfed reference group } \\
(n=160)\end{array}$ & $\begin{array}{l}\text { From birth to } 2 \\
\text { mo of life }\end{array}$ & $\begin{array}{l}\text { Hempel } \\
\text { BSID }\end{array}$ & $\begin{array}{l}6,12,18 \mathrm{mo} \\
18 \mathrm{mo}\end{array}$ & $\begin{array}{l}\text { No significant differences in MDI } \\
\text { nor in PDI between groups }\end{array}$ \\
\hline 6 & $\begin{array}{l}\text { Birch EE et al. } \\
2005^{(90)} / \text { USA }\end{array}$ & $\begin{array}{l}\text { Infant formula supplemented } \\
\text { with: DHA: } 0.36 \%+\text { AA: } \\
0.72 \%(n=51)\end{array}$ & $\begin{array}{l}\text { Standard Infant formula } \\
\quad(n=52) \\
\text { No breastfed reference } \\
\text { group }\end{array}$ & $\begin{array}{l}\text { From birth to } 52 \\
\text { weeks of age }\end{array}$ & $\begin{array}{l}\text { Weight, length } \\
\text { Sweep VEP Acuity } \\
\text { Random dot stereoa- } \\
\text { cuity }\end{array}$ & $\begin{array}{l}6,17,26 \\
39,52 \mathrm{w}\end{array}$ & $\begin{array}{l}\text { No differences in growth par- } \\
\text { ameters between groups } \\
\text { Infants in the LCPUFA group had a } \\
\text { better visual acuity than control } \\
\text { group at } 6,17,26 \text { and } 52 \mathrm{w} \\
\text { Steroacuity was significantly better } \\
\text { in the LCP-supplemented group } \\
\text { at } 17 \mathrm{wk} \text {, but not at } 39 \mathrm{wk} \text {. }\end{array}$ \\
\hline
\end{tabular}




\begin{tabular}{|c|c|c|c|c|c|c|c|}
\hline \multirow[b]{2}{*}{$\mathrm{N}^{\circ}$} & \multirow[b]{2}{*}{$\begin{array}{l}\text { Author/publication } \\
\text { year/country }\end{array}$} & \multirow[b]{2}{*}{$\begin{array}{l}\text { Intervention } \\
\text { (n-3 LC-PUFA dose/day) }\end{array}$} & \multirow[b]{2}{*}{ Control } & \multirow[b]{2}{*}{ Period } & \multicolumn{2}{|c|}{ Growth \& Neurological examination } & \multirow[b]{2}{*}{$\begin{array}{l}\text { Growth \& Neurodevelopment } \\
\text { outcomes }\end{array}$} \\
\hline & & & & & $\begin{array}{l}\text { Anthropometry and } \\
\text { Neurological Test }\end{array}$ & Age & \\
\hline 7 & $\begin{array}{l}\text { Ben XM et al. } \\
2004^{(91} / \text { China }\end{array}$ & $\begin{array}{l}\text { Infant formula supplemented } \\
\text { with: DHA + AA. The LCPUFA } \\
\text { content of the formula was not } \\
\text { clear. }(n=69)\end{array}$ & $\begin{array}{l}\text { Standard Infant formula } \\
\quad(n=52) \\
\text { Breastfed reference group } \\
\quad(n=26)\end{array}$ & $\begin{array}{l}\text { From birth to } 6 \\
\text { mo of life }\end{array}$ & $\begin{array}{l}\text { Growth } \\
\text { BSID }\end{array}$ & $\begin{array}{c}6 \mathrm{mo} \\
3,6 \mathrm{mo}\end{array}$ & $\begin{array}{l}\text { No significant differences in weight, } \\
\text { length or head circumference } \\
\text { between groups at } 6 \text { mo } \\
\text { No significant differences in MDI } \\
\text { nor in PDI between groups }\end{array}$ \\
\hline 8 & $\begin{array}{l}\text { Auestad N et al. } \\
2003^{(80)} / \text { USA }\end{array}$ & $\begin{array}{l}\text { Infant formula supplemented } \\
\text { with: DHA: } 0.13 \%+\text { AA: } \\
0.45 \%(n=46) \\
\text { Or only with: DHA: } 0.20 \% \\
(n=43)\end{array}$ & $\begin{array}{l}\text { Standard Infant formula } \\
\quad(n=45) \\
\text { Breastfed reference group } \\
\quad(n=63)\end{array}$ & $\begin{array}{l}\text { First } 12 \text { mo of } \\
\text { life, sole } \\
\text { source of } \\
\text { nutrition until } \\
\approx 4 \text { mo of } \\
\text { age }\end{array}$ & $\begin{array}{l}\text { Weight, length and } \\
\text { HC } \\
\text { Sweep VEP Acuity } \\
\text { Teller cards } \\
\text { Stanford Binet IQ } \\
\text { McArthur CDI } \\
\text { Peabody Picture } \\
\text { Vocabulary Test }\end{array}$ & $39 \mathrm{mo}$ & $\begin{array}{l}\text { No differences in growth between } \\
\text { groups } \\
\text { No significant differences in Sweep } \\
\text { VEP between groups at } 12 \text { mo } \\
\text { No statistical differences in visual } \\
\text { acuity using Teller cards at } 3 y \\
\text { No differences between groups in } \\
\text { the Stanford Binet IQ at } 39 \text { mo } \\
\text { No differences in cognitive and } \\
\text { language assessment at } 39 \text { mo }\end{array}$ \\
\hline 9 & $\begin{array}{l}\text { Lucas A et al. } \\
2002^{(81 / \text { England }}\end{array}$ & $\begin{array}{l}\text { Infant formula supplemented } \\
\text { with: DHA: } 0.32 \%+\text { AA: } \\
0.30 \%(n=154)\end{array}$ & $\begin{array}{l}\text { Standard Infant formula } \\
\quad(n=155) \\
\text { Breastfed reference group } \\
\quad(n=138)\end{array}$ & $\begin{array}{l}\text { From birth to } 6 \\
\text { mo of life }\end{array}$ & $\begin{array}{l}\text { Weight, length and } \\
\text { HC } \\
\text { BSID } \\
\text { Knobloch, Passama- } \\
\text { nick and Sherrads' } \\
\text { tests }\end{array}$ & $\begin{array}{l}6,9,18 \mathrm{mo} \\
18 \mathrm{mo} \\
9 \mathrm{mo}\end{array}$ & $\begin{array}{l}\text { No significant differences in weight, } \\
\text { length or head } \\
\text { circumference between groups at } \\
4,6,9,18 \text { mo } \\
\text { No significant differences in MDI } \\
\text { nor in PDI between groups }\end{array}$ \\
\hline 10 & $\begin{array}{l}\text { Auestad N et al. } \\
2001^{(92)} / \text { USA }\end{array}$ & $\begin{array}{l}\text { Infant formula supplemented } \\
\text { (egg/TG): DHA: } 0 \cdot 13 \%+\text { AA: } \\
\text { 0.45\% }(n=80) \text { or (fish/fungus } \\
\text { oil: DHA: } 0.13 \%+\text { AA: } 0.45 \% \\
\text { ( } n=82)\end{array}$ & $\begin{array}{l}\text { Standard Infant formula } \\
\quad(n=77) \\
\text { Breastfed reference group } \\
\quad(n=82)\end{array}$ & $\begin{array}{l}\text { First } 12 \text { mo of } \\
\text { life, sole } \\
\text { source of } \\
\text { nutrition until } \\
\approx 4 \text { mo of } \\
\text { age }\end{array}$ & $\begin{array}{l}\text { Growth } \\
\text { Teller acuity cards } \\
\text { Fagan test of infant } \\
\text { intelligence } \\
\text { BSID } \\
\text { McArthur's CDI } \\
\text { Parental reporting of } \\
\text { infant temperament }\end{array}$ & $\begin{array}{c}1,2,4,6 \\
9,12 \mathrm{mo} \\
2,4,6,12 \\
14 \mathrm{mo} \\
6,9 \mathrm{mo} \\
6,12 \mathrm{mo} \\
6,12 \mathrm{mo} \\
9,14 \mathrm{mo} \\
6,12 \mathrm{mo}\end{array}$ & $\begin{array}{l}\text { No significant differences in weight, } \\
\text { length or head circumference } \\
\text { between groups at } 4,6 \text { mo } \\
\text { No significant differences in visual } \\
\text { acuity between groups using } \\
\text { Teller cards } \\
\text { No statistical differences between } \\
\text { groups in the Fagan Test } \\
\text { No significant differences in MDI } \\
\text { nor in PDI between groups at } 6 \\
\text { mo or } 1 \mathrm{y} \text {. }\end{array}$ \\
\hline 11 & $\begin{array}{l}\text { Hoffman DR et al. } \\
2000^{(34)} / \text { USA }\end{array}$ & $\begin{array}{l}\text { Infant formula supplemented } \\
\text { with(microalgal/microfungal } \\
\text { LCP): DHA: } 0.36 \%+\text { AA: } \\
\text { 0.72\% }(n=27) \\
\text { Or only with: DHA: } 0.36 \% \\
(n=26)\end{array}$ & $\begin{array}{l}\text { Standard Infant formula } \\
\quad(n=26) \\
\text { Breastfed reference group } \\
\quad(n=29)\end{array}$ & $\begin{array}{l}\text { From birth to } 17 \\
\text { weeks of life }\end{array}$ & $\begin{array}{l}\text { Sweep VEP Acuity } \\
\text { ERG }\end{array}$ & $\begin{array}{c}6,17,26,52 \\
\text { weeks } \\
6 \mathrm{w}, 17 \mathrm{w} \\
1 \mathrm{y}\end{array}$ & $\begin{array}{l}\text { Better visual acuity at both } 17 \text { and } \\
52 \text { weeks of age. } \\
\text { More mature electroretinographic } \\
\text { responses at } 6 \text { weeks of age. } \\
\text { Supplementation leads to better } \\
\text { visual function later in life (52w). }\end{array}$ \\
\hline 12 & $\begin{array}{l}\text { Lapillonne A et al. } \\
2000^{(93} / \text { France }\end{array}$ & $\begin{array}{l}\text { Infant formula supplemented } \\
\text { with: DHA: } 0.31 \%(n=12)\end{array}$ & $\begin{array}{l}\text { Standard Infant formula } \\
\quad(n=12) \\
\text { No breastfed reference } \\
\text { group }\end{array}$ & $\begin{array}{l}\text { From birth to } 4 \\
\text { mo of life }\end{array}$ & $\begin{array}{l}\text { Weight, Length and } \\
\text { HC }\end{array}$ & $2,4 \mathrm{mo}$ & $\begin{array}{l}\text { No differences in weight, length or } \\
\text { head circumference between } \\
\text { groups }\end{array}$ \\
\hline 13 & $\begin{array}{l}\text { Agostoni C et al. } \\
2000^{(82)} / \text { Italy }\end{array}$ & $\begin{array}{l}\text { Infant formula supplemented } \\
\text { with: DHA: } 0.30 \%+\mathrm{AA} \text { : } \\
0.44 \%(n=29)\end{array}$ & $\begin{array}{l}\text { Standard Infant formula } \\
\quad(n=31) \\
\text { Breastfed reference group }\end{array}$ & $\begin{array}{l}\text { From birth to } 4 \\
\text { mo of life }\end{array}$ & Bruner-Lezine test & $24 \mathrm{mo}$ & $\begin{array}{l}\text { No differences on Developmental } \\
\text { Quotient (DQ) at } 24 \mathrm{mo}\end{array}$ \\
\hline
\end{tabular}




\begin{tabular}{|c|c|c|c|c|c|c|c|}
\hline \multirow[b]{2}{*}{$\mathrm{N}^{\circ}$} & \multirow[b]{2}{*}{$\begin{array}{l}\text { Author/publication } \\
\text { year/country }\end{array}$} & \multirow[b]{2}{*}{$\begin{array}{l}\text { Intervention } \\
\text { (n-3 LC-PUFA dose/day) }\end{array}$} & \multirow[b]{2}{*}{ Control } & \multirow[b]{2}{*}{ Period } & \multicolumn{2}{|c|}{ Growth \& Neurological examination } & \multirow[b]{2}{*}{$\begin{array}{l}\text { Growth \& Neurodevelopment } \\
\text { outcomes }\end{array}$} \\
\hline & & & & & $\begin{array}{l}\text { Anthropometry and } \\
\text { Neurological Test }\end{array}$ & Age & \\
\hline 14 & $\begin{array}{l}\text { Birch EE et al. } \\
2000^{(83)} / \text { USA }\end{array}$ & $\begin{array}{l}\text { Infant formula supplemented with } \\
\text { (microalgal/microfungal LCP): } \\
\text { DHA: } 0.36 \%+\text { AA: } 0.72 \% \\
\text { ( } n=19) \\
\text { Or only with: DHA: } 0.36 \% \\
\quad(n=17)\end{array}$ & $\begin{array}{l}\text { Standard Infant formula } \\
\quad(n=20) \\
\text { Breastfed reference group } \\
\quad(n=20)\end{array}$ & $\begin{array}{l}\text { From within five } \\
\text { days of birth } \\
\text { till } 17 \text { weeks } \\
\text { of life }\end{array}$ & $\begin{array}{l}\text { Weight } \\
\text { Sweep VEP Acuity } \\
\text { BSID II }\end{array}$ & $\begin{array}{c}4,12 \mathrm{mo} \\
18 \mathrm{mo}\end{array}$ & $\begin{array}{l}\text { No differences in growth between } \\
\text { groups } \\
\text { Better VEP acuity at } 4 \text { mo was } \\
\text { associated with a better MDI and } \\
\text { PDI score at } 18 \text { mo. } 7 \text { points } \\
\text { increase of MDI in the DHA sup- } \\
\text { plemented groups. }\end{array}$ \\
\hline 15 & $\begin{array}{l}\text { Makrides M et al. } \\
2000^{(84)} / \text { Australia }\end{array}$ & $\begin{array}{l}\text { Infant formula supplemented } \\
\text { with: DHA: } 0.34 \%+\text { AA: } \\
0.34 \%(n=28) \\
\text { Or only with: DHA }(0.34 \%) \\
(n=27)\end{array}$ & $\begin{array}{l}\text { Standard Infant formula } \\
\quad(n=28) \\
\text { Breastfed reference group } \\
\quad(n=63)\end{array}$ & $\begin{array}{l}\text { From the } 5 \text { days } \\
\text { to } 4 \text { mo of life }\end{array}$ & $\begin{array}{l}\text { Weight, length, head } \\
\quad \text { circumference } \\
\text { Steady state VEP } \\
\text { BSID }\end{array}$ & $\begin{array}{l}6,16,34 \\
\text { weeks } 1,2 \\
y \\
1 y \& 2 y\end{array}$ & $\begin{array}{l}\text { No differences in growth par- } \\
\text { ameters between groups at } 4 \text { mo } \\
\text { Better VEP visual acuity in the sup- } \\
\text { plemented group at } 4 \text { mo, but no } \\
\text { differences at } 7-8 \text { mo } \\
\text { No significant differences in MDI } \\
\text { nor in PDI between groups }\end{array}$ \\
\hline 16 & $\begin{array}{l}\text { Morris G et al. } \\
2000^{(94)} \text { Wales }\end{array}$ & $\begin{array}{l}\text { Infant formula supplemented } \\
\text { with: DHA: } 0.20 \%+\text { AA: } \\
0.40 \%(n=54)\end{array}$ & $\begin{array}{l}\text { Standard Infant formula } \\
\quad(n=55) \\
\text { No breastfed reference } \\
\text { group }\end{array}$ & $\begin{array}{c}\text { From birth to } 4 \\
\text { mo of life }\end{array}$ & Growth & $\begin{array}{c}6 \text { weeks; } \\
3,6,12 \\
\text { mo }\end{array}$ & $\begin{array}{l}\text { No differences in weight between } \\
\text { groups at } 6 \mathrm{mo}\end{array}$ \\
\hline 17 & $\begin{array}{l}\text { Lucas A et al. } \\
1999^{(33)} / \text { England }\end{array}$ & $\begin{array}{l}\text { Infant formula supplemented } \\
\text { with: DHA: } 0.32 \%+\text { AA: } \\
0.30 \%(n=154)\end{array}$ & $\begin{array}{l}\text { Standard Infant formula } \\
\quad(n=155) \\
\text { Breastfed reference group } \\
\quad(n=138)\end{array}$ & $\begin{array}{l}\text { From birth to } 6 \\
\text { mo of life }\end{array}$ & $\begin{array}{l}\text { Weight, Length, Head } \\
\text { circumference, } \\
\text { mid-upper arm cir- } \\
\text { cumference, sum } \\
\text { skinfolds } \\
\text { BSID } \\
\text { Knobloch, Passama- } \\
\text { nick and Sherrads' } \\
\text { tests }\end{array}$ & $\begin{array}{l}6,9,18 \mathrm{mo} \\
18 \mathrm{mo} \\
9 \mathrm{mo}\end{array}$ & $\begin{array}{l}\text { No differences in weight, length or } \\
\text { head circumference between } \\
\text { groups at } 6 \text { mo } \\
\text { No significant differences in MDI } \\
\text { nor in PDI between groups } \\
\text { No significant differences between } \\
\text { groups in Knobloch, Passamanik } \\
\text { and Sherrards Development } \\
\text { Screening } \\
\text { Inventory }\end{array}$ \\
\hline 18 & $\begin{array}{l}\text { Makrides M } \\
\text { et al.1999 }{ }^{(85)} / \text { Austr- } \\
\text { alia }\end{array}$ & $\begin{array}{l}\text { Infant formula supplemented } \\
\text { with: DHA: } 0.34 \%+\text { AA: } \\
0.34 \%(n=28) \\
\text { Or only with: DHA (0.34\%) } \\
(n=27)\end{array}$ & $\begin{array}{l}\text { Standard Infant formula } \\
(n=28) \\
\text { Breastfed reference group } \\
\quad(n=63)\end{array}$ & $\begin{array}{l}\text { From birth to } 4 \\
\text { mo of life }\end{array}$ & $\begin{array}{l}\text { Weight, length, head } \\
\text { circumference }\end{array}$ & $\begin{array}{l}6,16,34 \\
\text { weeks } \\
\text { and } 1 \mathrm{y} \\
\& 2 \mathrm{y}\end{array}$ & $\begin{array}{l}\text { No differences in growth } \\
\text { parameters }\end{array}$ \\
\hline 19 & $\begin{array}{l}\text { Birch EE et al. } \\
1998^{(86)} / \text { USA }\end{array}$ & $\begin{array}{l}\text { Infant formula supplemented } \\
\text { with: DHA: } 0.36 \%+\text { AA: } \\
0.72 \%(n=27) \\
\text { Or only with: DHA: } 0.36 \% \\
(n=26)\end{array}$ & $\begin{array}{l}\text { Standard Infant formula } \\
\quad(n=26) \\
\text { Breastfed reference group } \\
\quad(n=29)\end{array}$ & $\begin{array}{l}\text { From within five } \\
\text { days of birth } \\
\text { till } 17 \text { weeks } \\
\text { of life }\end{array}$ & $\begin{array}{l}\text { Growth } \\
\text { Sweep VEP Acuity } \\
\text { Forced-choice prefer- } \\
\text { ential looking acuity } \\
\text { (FPL) }\end{array}$ & $\begin{array}{c}6,17,26,52 \\
\text { wk } \\
17,52 \mathrm{wk}\end{array}$ & $\begin{array}{l}\text { No differences in weight, length or } \\
\text { head circumference between } \\
\text { groups at } 6 \text { mo } \\
\text { Infants in the LCPUFA group had a } \\
\text { better visual acuity than control } \\
\text { group }\end{array}$ \\
\hline 20 & $\begin{array}{l}\text { Scott DT et al. } \\
1998^{(87)} / \text { USA }\end{array}$ & $\begin{array}{l}\text { Infant formula supplemented } \\
\text { with: DHA: } 0.13 \%+\text { AA: } \\
0.45 \%(n=46) \\
\text { Or only with: DHA: } 0.20 \% \\
(n=43)\end{array}$ & $\begin{array}{l}\text { Standard Infant formula } \\
\quad(n=45) \\
\text { Breastfed reference group } \\
\quad(n=63)\end{array}$ & $\begin{array}{l}\text { First } 12 \text { mo of } \\
\text { life, sole } \\
\text { source of } \\
\text { nutrition until } \\
\approx 4 \text { mo of } \\
\text { age }\end{array}$ & $\begin{array}{l}\text { BSID } \\
\text { McArthur CDI } \\
\text { Peabody Picture } \\
\text { Vocabulary Test }\end{array}$ & $1 y$ & $\begin{array}{l}\text { No significant differences in MDI } \\
\text { nor in PDI between groups } \\
\text { DHA group scored lower on the } \\
\text { Vocabulary Comprehension and } \\
\text { Production Scales } \\
\text { Significant negative correlations } \\
\text { between DHA levels and vocabu- } \\
\text { lary outcomes. }\end{array}$ \\
\hline
\end{tabular}


Table 3. Continued

\begin{tabular}{|c|c|c|c|c|c|c|c|}
\hline \multirow[b]{2}{*}{$\mathrm{N}^{\circ}$} & \multirow[b]{2}{*}{$\begin{array}{l}\text { Author/publication } \\
\text { year/country }\end{array}$} & \multirow[b]{2}{*}{$\begin{array}{l}\text { Intervention } \\
\text { (n-3 LC-PUFA dose/day) }\end{array}$} & \multirow[b]{2}{*}{ Control } & \multirow[b]{2}{*}{ Period } & \multicolumn{2}{|c|}{ Growth \& Neurological examination } & \multirow[b]{2}{*}{$\begin{array}{l}\text { Growth \& Neurodevelopment } \\
\text { outcomes }\end{array}$} \\
\hline & & & & & $\begin{array}{l}\text { Anthropometry and } \\
\text { Neurological Test }\end{array}$ & Age & \\
\hline 21 & $\begin{array}{l}\text { Willatts P et al. } \\
1998^{(95)} / \text { Scotland }\end{array}$ & $\begin{array}{l}\text { Infant formula supplemented } \\
\text { with: DHA: } 0 \cdot 15-0.25 \%+\mathrm{AA} \text { : } \\
0.30-0 \cdot 40 \%(n=34)\end{array}$ & $\begin{array}{l}\text { Standard Infant formula } \\
\quad(n=38) \\
\text { No breastfed reference } \\
\text { group }\end{array}$ & $\begin{array}{l}\text { From birth to } 4 \\
\text { mo of life }\end{array}$ & Problem solving tests & $10 \mathrm{mo}$ & $\begin{array}{l}\text { LCPUFA-supplemented infants had } \\
\text { significantly more intentional sol- } \\
\text { utions than infants who received } \\
\text { control formula }\end{array}$ \\
\hline 22 & $\begin{array}{l}\text { Auestad N et al. } \\
1997^{(88)} / \text { USA }\end{array}$ & $\begin{array}{l}\text { Infant formula supplemented } \\
\text { with: DHA: } 0.13 \%+\text { AA: } \\
0.45 \%(n=46) \\
\text { Or only with: DHA: } 0.20 \% \\
(n=43)\end{array}$ & $\begin{array}{l}\text { Standard Infant formula } \\
\quad(n=45) \\
\text { Breastfed reference group } \\
\quad(n=63)\end{array}$ & $\begin{array}{l}\text { First } 12 \text { mo of } \\
\text { life, sole } \\
\text { source of } \\
\text { nutrition until } \\
\approx 4 \text { mo of } \\
\text { age }\end{array}$ & $\begin{array}{l}\text { Weight, Length, HC } \\
\text { Sweep VEP Acuity } \\
\text { Teller cards }\end{array}$ & $\begin{array}{c}1,2,4,6,9,12 \\
\mathrm{mo}\end{array}$ & $\begin{array}{l}\text { No differences in growth between } \\
\text { the two groups. } \\
\text { No significant differences in visual } \\
\text { acuity between groups using } \\
\text { Sweep VEP acuity or Teller cards } \\
\text { in all ages }\end{array}$ \\
\hline 23 & $\begin{array}{l}\text { Agostoni C } \\
\text { et al.1997 } \\
\text { (32)/ltaly }\end{array}$ & $\begin{array}{l}\text { Infant formula supplemented } \\
\text { with: DHA: 0.30\% + AA: } \\
0.44 \%(n=29)\end{array}$ & $\begin{array}{l}\text { Standard Infant formula } \\
\quad(n=31) \\
\text { Breastfed reference group } \\
\quad(n=30)\end{array}$ & $\begin{array}{l}\text { From birth to } 4 \\
\text { mo of life }\end{array}$ & Bruner-Lezine test & $4,12,24 \mathrm{mo}$ & $\begin{array}{l}\text { No differences on Developmental } \\
\text { Quotient (DQ) at } 12 \mathrm{mo}\end{array}$ \\
\hline 24 & $\begin{array}{l}\text { Carlson SE } \\
\quad \text { et al.1996 } \\
(96) / \mathrm{USA}\end{array}$ & $\begin{array}{l}\text { Infant formula supplemented } \\
\text { with: DHA: } 0 \cdot 10 \%+\text { AA: } \\
0.43 \%(n=19)\end{array}$ & $\begin{array}{l}\text { Standard Infant formula } \\
\quad(n=20) \\
\text { Breastfed reference group } \\
\quad(n=19)\end{array}$ & $\begin{array}{l}\text { From birth to } 1 \\
y \text { of life }\end{array}$ & $\begin{array}{l}\text { Visual Acuity } \\
\text { Teller acuity cards }\end{array}$ & $\begin{array}{c}2,4,6,9,12 \\
\text { mo }\end{array}$ & $\begin{array}{l}\text { No significant differences in visual } \\
\text { acuity between groups using } \\
\text { Teller cards }\end{array}$ \\
\hline 25 & $\begin{array}{l}\text { Agostoni C } \\
\text { et al.1995 } \\
(89) / \text { Italy }\end{array}$ & $\begin{array}{l}\text { Infant formula supplemented } \\
\text { with: DHA: 0.30\% + AA: } \\
0.44 \%(n=29)\end{array}$ & $\begin{array}{l}\text { Standard Infant formula } \\
\quad(n=31) \\
\text { Breastfed reference group } \\
\quad(n=30)\end{array}$ & $\begin{array}{l}\text { From birth to } 4 \\
\text { mo of life }\end{array}$ & Bruner-Lezine test & $4 \mathrm{mo}$ & $\begin{array}{l}\text { Higher Developmental Quotient } \\
\text { (DQ) at } 4 \mathrm{mo}\end{array}$ \\
\hline 26 & $\begin{array}{l}\text { Makrides M et al. } \\
1995^{(97)} / \text { Australia }\end{array}$ & $\begin{array}{l}\text { Infant formula supplemented } \\
\text { with: DHA: } 0.35 \%+\text { EPA and } \\
\text { GLA }(n=13)\end{array}$ & $\begin{array}{l}\text { Standard Infant formula } \\
\quad(n=19) \\
\text { Breastfed reference group } \\
\quad(n=28)\end{array}$ & $\begin{array}{l}\text { From birth until } \\
30 \text { weeks of } \\
\text { life }\end{array}$ & $\begin{array}{l}\text { VEP Acuity } \\
\text { BSID }\end{array}$ & $\begin{array}{l}16,30 \\
\text { weeks } \\
1 \mathrm{y}\end{array}$ & $\begin{array}{l}\text { Infants in the LC-PUFA group had } \\
\text { better visual acuity at } 4 \text { mo } \\
\text { No significant differences in MDI } \\
\text { nor in PDI between groups }\end{array}$ \\
\hline
\end{tabular}


Table 4. Significant effects found of n-3 LCPUFA supplementation during Pregnancy or Lactation Child Visual Development

\begin{tabular}{lcc}
\hline Outcome & $\mathrm{N}$ & Mean difference $[95 \% \mathrm{Cl}]$ \\
\hline $\begin{array}{l}\text { Supplementation during pregnancy } \\
\text { Judge et al. 2007 }\end{array}$ & & \\
Visual acuity scores at 4 months & 30 & $0.5[-0.4,1.4]^{*}$ \\
$\begin{array}{l}\text { Malcolm et al. 2003 } \\
\text { (50) }\end{array}$ & & \\
$\begin{array}{l}\text { Mean peak latency of transient } \\
\quad \text { flash VEP }\end{array}$ & 34 & $-35.5[-69.4,-1.6]^{*}$ \\
$\quad$ N3 at 50 weeks PCA & & \\
$\begin{array}{l}\text { Mothers' supplementation during } \\
\text { lactation }\end{array}$ & & \\
Jensen et al. 2005 ${ }^{(70)}$ & \\
$\quad$ Teller acuity card at 4 months & 147 & $0.30(0.09,0.51)^{*}$ \\
$\quad$ Teller acuity card at 8 months & 147 & $-1.2(-1.38,-1.02)^{*}$
\end{tabular}

$\mathrm{Cl}=$ confidence interval, $\mathrm{PCA}=$ post-conceptional age. $\mathrm{VEP}=$ visual evoked potential, $\mathrm{cpd}=$ cycles per degree, $\mathrm{ms}$ : miliseconds, $\mu \mathrm{V}=$ microvoltium, ${ }^{*}=$ significant difference $(P<0.05)$

blood $^{(55)}$. Moreover, children whose mothers had higher DHA content in erythrocyte phosphatidylethanolamine (PE) at delivery were more likely to have a Mental Processing Composite (MPC) score of the Kaufman ABC over the median at 6.5 yrs. Likewise higher AA/DHA ratio in maternal erythrocyte PE at delivery was associated with greater proportion of low MPC scores (below the median) ${ }^{(56)}$

Lauritzen et al. demonstrated that passive vocabulary at $1 \mathrm{yr}$ of age was lower in children whose mothers were supplemented with fish oil during lactation, compared to those babies whose mothers received olive oil; in the same study the authors reported that word comprehension at $1 \mathrm{yr}$ of age was inversely associated with erythrocyte-DHA content at 4 mo additionally a small effect of breast-milk DHA was noted on early language development ${ }^{(71)}$. Jensen et al. in 2005 report a benefit of DHA supplementation during lactation at 2.5 years of age, despite no differences in infancy ${ }^{(70)}$. The supplemented group from this cohort of children was reported to perform better on a test of sustained attention at the age of 5 years ${ }^{(74)}$. Recently, Makrides et al. ${ }^{(64)}$ have shown that mean cognitive composite scores and mean language composite scores of children in the DHA group of mothers supplemented during pregnancy did not differ from children in the control group.

Cheatham et al. ${ }^{(74)}$ reported that early fish oil supplementation during lactation could have a negative effect on later cognitive abilities, suggesting a need to target an optimun DHA level, below and above which, there could be detrimental consequences to brain development.

Growth. Most studies included in this review showed no statistical differences after supplementation with DHA during pregnancy and/or during lactation in birth weight, length, weight for length or ponderal index at different ages $^{(54,58-59,61-62,64)}$.

Smuts et al. ${ }^{(61)}$ showed no significant differences between groups, but demonstrated that DHA intake correlates with birth weight. Tofail et al. ${ }^{(54)}$ investigated the effect of fish oil (1.2 g DHA and 1.8g eicosapentaenoic acid, EPA 20:5 n-3, per day) from 25 weeks gestation until birth on growth and development in 249 mother-infant pairs from a very poor area of Bangladesh. Birth weight, length, head circumference and ponderal index did not differ between groups at birth or at 10 months. Ramakrishnan et al. ${ }^{(58)}$ and Stein et al. ${ }^{(62)}$ studied the effect of DHA supplementation ( $400 \mathrm{mg} /$ day) compared with placebo in 1094 pregnant women from Cuernavaca (Mexico), with a low background dietary intake of DHA $(\approx 55 \mathrm{mg} /$ day). Mean gestational age at birth, birth weight, length and head circumference did not differ between groups. However, the babies from primiparous women who received DHA were heavier $(+99 \mathrm{~g})$ and had larger head circumferences $(+0.5 \mathrm{~cm})$ at birth compared to controls. These differences were not shown in multigravida women ${ }^{(58)}$. Makrides et al. ${ }^{(64)}$ in a randomised clinical trial on 2399 women, supplemented or not with $800 \mathrm{mg} /$ day of DHA $+100 \mathrm{mg} /$ day of EPA, showed no significant differences between groups. Group differences in birth size were largely explained by gestational age at birth. Finally, Lucia et al. ${ }^{(69)}$ showed significant lower BMI and birth weight in babies from DHA supplemented mothers, at 1, 3 and 21 mo.

Table 5. Significant Effects found of $n-3$ LCPUFA Supplementation during Pregnancy and Lactation on Child Neurodevelopment

\begin{tabular}{|c|c|c|}
\hline Outcome & $\mathrm{N}$ & Mean difference $[95 \% \mathrm{Cl}]$ \\
\hline \multicolumn{3}{|l|}{$\begin{array}{l}\text { n-3 LCPUFA Supplementation during pregnancy } \\
\text { Judge et al. } 2007^{(53)}\end{array}$} \\
\hline \multicolumn{3}{|l|}{ The 2-step problem-solving test at 9 months } \\
\hline Intention score: cloth average & 29 & $0.6[-0.1,1.4]$ \\
\hline Intention score: cover average & 29 & $0.7[-0.6,2 \cdot 0]$ \\
\hline Intention score: total average & 29 & $1.3[-0.6,3.2]^{*}$ \\
\hline Intentional solutions: cloth & 29 & $1 \cdot 1[0.01,2 \cdot 2]$ \\
\hline Intentional solutions: cover & 29 & $0.8[-0.3,1.9]^{*}$ \\
\hline Intentional solutions: total & 29 & $0.8[-0.2,1.8]^{\star}$ \\
\hline \multicolumn{3}{|l|}{$\begin{array}{l}n-3 \text { LCPUFA Supplementation during Pregnancy } \\
\text { \& Lactation }\end{array}$} \\
\hline \multicolumn{3}{|l|}{ Helland et al. $2003^{(67)}$} \\
\hline $\begin{array}{l}\text { K-ABC mental processing composite at } 4 \text { year } \\
n-3 \text { LCPUFA Supplementation during Lactation } \\
\text { Lauritzen et al. } 2005^{(72)}\end{array}$ & 84 & $4 \cdot 1[-0.2,8 \cdot 4]^{\star}$ \\
\hline MacArthur CDI vocabulary comprehension at 1 year & 89 & $-17.0[-34.6,0.6]^{\star}$ \\
\hline
\end{tabular}




\section{Effects of LCPUFAs supplementation in term infants}

Visual acuity. The main results are shown in Table 6.

Some of the included studies exploring the effect of receiving DHA supplementation in early life on visual acuity, using different methodologies (Sweep VEP, Steady state VEP, Teller Acuity Cards, HOTV cards) have reported either no significant effects or minor effects compared to control groups or breast fed infants at different stages of infant development ${ }^{(80,84-85,88,92)}$. Makrides et al ${ }^{(97)}$ in a randomized control trial to assess the effect of infant formula supplemented with $0.35 \%$ of DHA, given from birth to 30 weeks of postnatal life, reported better visual acuity at $4 \mathrm{mo}$ in the supplemented infants compared to control group.

Birch et al ${ }^{(34,83,86)}$ have consistently demonstrated that DHA $(0.36 \%)$ supplementation with or without AA (0.72\%) during the first 17 weeks of life improved visual acuity at 17, 26 and 52 weeks, and steroacuity ${ }^{(80)}$ at 52 weeks of postnatal age measured using visual evoked responses and more mature electroretinographic responses at 6 weeks of age ${ }^{(34)}$. At 4 years, the supplemented group had a small but statistically significant effect on visual acuity using HOTV cards for the right eye $(P<0.03)$; while the control formula diet

Table 6. Significant Effects related to $n-3$ LCPUFA supplementation of infant formula on infant and child visual acuity

\begin{tabular}{|c|c|c|}
\hline Outcome & $\mathrm{N}$ & Mean Difference $[95 \% \mathrm{Cl}]$ \\
\hline \multicolumn{3}{|l|}{ Infant formula supplementation } \\
\hline \multicolumn{3}{|l|}{ Birch et al. $2010^{(76)}$} \\
\hline $\begin{array}{l}\text { Sweep VEP Acuity } 1.5,4,6,9,12 \\
\text { months }\end{array}$ & 256 & Data not available \\
\hline \multicolumn{3}{|l|}{ Birch et al. $2007^{(78)}$} \\
\hline \multicolumn{3}{|l|}{$\begin{array}{l}D H A+A A \text { supplemented vs normal } \\
\quad \text { term infant formula }\end{array}$} \\
\hline $\begin{array}{l}\text { HOTV acuity (logMAR) RE at } \\
4 \text { years }\end{array}$ & 36 & $0.042[0.00075,-0.00072]^{\star}$ \\
\hline \multicolumn{3}{|l|}{$\begin{array}{l}\text { DHA supplemented vs term infant } \\
\text { formula }\end{array}$} \\
\hline $\begin{array}{l}\text { HOTV acuity (logMAR) RE at } \\
4 \text { years }\end{array}$ & 35 & $0.053[0.014,-0.013]^{\star}$ \\
\hline \multicolumn{3}{|l|}{ Birch et al. $2005^{(90)}$} \\
\hline \multicolumn{3}{|l|}{$\begin{array}{l}D H A+A A \text { supplemented vs normal } \\
\text { term infant formula }\end{array}$} \\
\hline $\begin{array}{l}\text { Sweep VEP Acuity at } 4 \\
\text { months }\end{array}$ & 92 & $-0.07[-0.11,-0.03]^{\star}$ \\
\hline \multicolumn{3}{|l|}{ Hoffman et al. $2000^{(34)}$} \\
\hline \multicolumn{3}{|l|}{$\begin{array}{l}D H A+A A \text { supplemented vs normal } \\
\text { term infant formula }\end{array}$} \\
\hline $\begin{array}{l}\text { Sweep VEP Acuity (logMAR) at } \\
4 \text { months }\end{array}$ & 42 & $-0.06[-0.13,0.01]^{\star}$ \\
\hline $\begin{array}{l}\text { Sweep VEP Acuity (logMAR) at } \\
12 \text { months }\end{array}$ & 38 & $-0.13[-0.20,-0.06]^{\star}$ \\
\hline \multicolumn{3}{|l|}{$\begin{array}{l}\text { DHA supplemented vs term infant } \\
\text { formula }\end{array}$} \\
\hline $\begin{array}{l}\text { Sweep VEP Acuity (logMAR) at } \\
4 \text { months }\end{array}$ & 41 & $-0.08[-0.15,-0.01]^{\star}$ \\
\hline $\begin{array}{l}\text { Sweep VEP Acuity (logMAR) at } \\
12 \text { months }\end{array}$ & 40 & $-0.14[-0.21,-0.07]^{\star}$ \\
\hline \multicolumn{3}{|l|}{ Makrides et al. $1995^{(97)}$} \\
\hline $\begin{array}{l}\text { Steady state VEP Acuity (logMAR) } \\
\text { at } 4 \text { months }\end{array}$ & 26 & $-0.20[-0.32,-0.08]^{\star}$ \\
\hline
\end{tabular}

PCA = Postconceptional age, VEP = Visual Evoked Potentials, MAR: minimum angle of resolution, HOTV: Amblyopia Treatment Study (ATS) protocol and the Electronic Visual Acuity (EVA) system, $\mathrm{Cl}$ : Confidence Interval, ${ }^{*}=$ significant difference $(P<0.05)$. group had poorer visual acuity in the right eye compared to the breast-fed group $(P<0.004)$ as well as lower right eye acuity compared to the DHA containing formula group $(P<0.03)$; the DHA- and DHA + AA-supplemented groups did not differ significantly from the breast-fed group $^{(78)}$. Birch et al. ${ }^{(76)}$ recently have published the results of a new large sample size study from 244 healthy, term, formula-fed, singleton-birth infants (37-42 wk gestation; 2490-4200 g birth weight) randomized into four groups (DIAMOND study): $56 / 85(66 \%)$ in the control group, 64/83 (77\%) in the $0.32 \%$ DHA group, 59/84 (70\%) in the $0.64 \%$ DHA group, and $65 / 87(75 \%)$ in the $0.96 \%$ DHA group. All DHA supplemented formulas contained $0.64 \%$ arachidonic acid (AA). Infants were fed the assigned formulas until 12 months of age, and 141 children completed the 12-month feeding trial ${ }^{(75)}$. Infants fed control formula had significantly poorer VEP visual acuity at 12 mo of age than did infants fed any of the DHA-supplemented formulas $(P<0.001)$.

Neurodevelopment. The main results are shown in Table 7. Most studies ${ }^{(32,76,80,84,88,92,96-97)}$ included in this review were randomised controlled clinical trials reporting on the effect of DHA supplemented infant formula on neurodevelopment using different tests (BSID, Brunetz-Lezine, MacArthur Comunicative Development Inventory, Stanford Binet IQ, Hempel, Touwen, Knobloch, Passamanick and Sherrads' tests) at different ages; no significant differences were found at 6 mo to $9 \mathrm{yrs}$ of age. Willats et al. ${ }^{(95)}$ demonstrated that babies fed LCPUFA-supplemented infant formula had significantly more intentional solutions than infants who received control formula at $10 \mathrm{mo}$. Agostoni et al. ${ }^{(32,82,89)}$ evaluated the effect of infant formula supplemented with $0 \cdot 3 \%$ DHA plus $0.44 \%$ AA compared to a standard formula, using Brunet-Lezine test, demonstrating higher Developmental Quotient at $4 \mathrm{mo}$, but not at $1 \mathrm{y}$ and $2 \mathrm{y}$ in the supplemented infants. Birch et al. ${ }^{(88)}$ demonstrated 7 points increase of MDI in the DHA supplemented groups and no significant differences in PDI and Behavior Rating Scales scores at 18 mo compared to control group. They also reported that better VEP acuity at 4 mo was associated to a better MDI and PDI scores at 18 mo. Drover et al. ${ }^{(75)}$ confirmed the previous results assessing cognitive function in a new study including 131 children at $18 \mathrm{mo}$ of age using the more up to date BSID II reporting that MDI scores of DHA-supplemented children were higher than those who did not received DHA supplementation at 18 mo of age; moreover, DHA concentration of $0 \cdot 32 \%$ was adequate to improve cognitive function and higher concentrations did not confer additional benefit.

Growth. Some of the randomized clinical trial included in this review, using DHA plus or not in combination with $\mathrm{AA}^{(33,76,78,80-81,83-84,86,88,90-94)}$ reported this outcome. No studies found statistically significant differences between LCPUFA and control groups, even if the studies included a breast fed reference group.

\section{Discussion}

The aim of this systematic review of RCTs was to assess whether n-3 LCPUFA supplementation to pregnant and/or lactating 
Table 7. Significant Effects related to n-3 LCPUFA supplementation of infant formula on infant and child neurodevelopment. Data from the Bayley Scales for Infant Development (BSID)

\begin{tabular}{|c|c|c|}
\hline Outcome & $\mathrm{N}$ & Mean difference $[95 \% \mathrm{Cl}]$ \\
\hline \multicolumn{3}{|l|}{ Drover et al. $2011^{(75)}$} \\
\hline \multicolumn{3}{|l|}{$D H A+A A(0.32 \%)$} \\
\hline \multicolumn{3}{|l|}{$\begin{array}{l}\text { supplemented vs normal } \\
\text { term infant formula }\end{array}$} \\
\hline $\begin{array}{l}\text { MDI score at } 18 \text { months } \\
\text { Birch et al. } 2000^{(83)}\end{array}$ & 57 & $-6.80[7.38,4.02]^{*}$ \\
\hline$D H A+A A$ supplemented & & \\
\hline \multicolumn{3}{|l|}{$\begin{array}{l}\text { vs normal term infant } \\
\text { formula }\end{array}$} \\
\hline MDI score at 18 months & 39 & $7.30[0.78,13.82]^{*}$ \\
\hline PDI score at 18 months & 39 & $3.10[0.15,6.05]^{\star}$ \\
\hline
\end{tabular}

mothers, and to infant formula, could benefit term infants in their psychomotor, mental, visual acuity development and their physical growth. Evidence from the data obtained in the present review do not demonstrate that n-3 LCPUFA supplementation during prenatal or early life exert a clear and consistent short or long-term benefit of the offspring. Some recent large sample size studies included in this review reported favorable effects of n-3 LCPUFA supplementation on one specific domain of child development, or on visual acuity development using electrophysiological assessment. The effect on different measures of physical growth is null or minor in virtually all studies. Transient early differences tend to disappear in subsequent assessments. However, there is great heterogeneity among studies regarding the timing, type, concentration and duration of LCPUFA supplementation and of the outcomes assessed and methods used to assess the outcomes. Thus results of most studies are not comparable. For example, visual acuity development was measured at 4, 6, 12 months, 3 and 4 years, using sweep VEP, steady state VEP or teller cards. The neurodevelopmental outcomes were assessed at 3, 4, 6,1 2 months and at 2, 3, 4, 7 and 9 years in different studies, using different age-adapted tests. The only exception was physical growth was assessed at 4, 6, 12 months and 2, 3, 4 years in different studies, using standard physical measurements or $\mathrm{z}$ scores of such measurements.

SomeRCTs during pregnancy suggest that prenatal DHA status might have subtle positive effects on neurodevelopmental and behaviour outcome ${ }^{(70-74)}$, but whether these effects are maintained beyond early infancy remains a matter of discussion $^{(97-100)}$. Trials specifically addressing n-3 LCPUFA supplementation during pregnancy and/or lactation consistently show a direct dose-response relationship between DHA intake and mothers' DHA concentration in plasma or erythrocyte phospholipids or in human milk, respectively, but have not consistently demonstrated benefits on developmental outcomes in children ${ }^{(48-56,64-65,67-68)}$. It is important to note that some of these RCTs have agreed with the observational and epidemiological results ${ }^{(46)}$, indicating that a better $\mathrm{AA} / \mathrm{DHA}$ status during pregnancy and lactation is related to a better neurodevelopment outcome in children born at term.
Postnatal supplementation to improve neurodevelopment, has shown conflicting results in term infants. The follow up results in young children suggest that neurodevelopment and cognitive abilities are also enhanced by early provision of n-3 LCPUFAs through breast milk or DHA-fortified foods. Breast fed infants also require n-3 LCPUFAs after weaning to achieve optimal visual acuity at 12 months of age ${ }^{(32,36,101)}$. Jensen et $a l{ }^{(70,74)}$ reported significant differences in psychomotor development and sustained attention at long term (30 mo and 5 years), favouring the breastfeeding mothers supplemented with DHA.

Makrides et al. ${ }^{(64,84,97)}$ and Birch et al..$^{(34,76,78,86,90)}$ have conducted the largest studies and have shown, in different studies with multiple repeated measures, that n-3 LCPUFA supplementation to infant formula benefits visual acuity and mental development indices for up to 4 years. In addition, it has been reported benefits of LCPUFA supplementation on MDI scores at 18 months ${ }^{(74,83)}$ and better problem solving skills at 10 months of age ${ }^{(95)}$. However, these beneficial effects on vision and neurodevelopment have not been replicated in other good quality studies ${ }^{(32-33,77,79,81-82,85,88,92,94)}$. In 2003, a meta-regression analysis of seven trials in term infants showed that the DHA dose in milk formula was positively related to visual acuity measurements at age 4 months ${ }^{(36)}$. In 2010, Beyerlein et al. ${ }^{(44)}$ analysed the results of 4 large randomised clinical trials in a meta-analysis and they could not find a clinically meaningful effect on the neurodevelopment and visual acuity in children that received LCPUFA supplemented formula. This served to further raise the discussion on whether it was valid to continue supplementing DHA to breastfeeding mothers ${ }^{(72-73)}$ and to term infants fed infant formula ${ }^{(87)}$. Furthermore these investigators reported potential adverse effects, suggesting that there is an optimum DHA level below and above which DHA might be detrimental to the developing brain. We conclude that based on present evidence there is still no clear evidence of long-term beneficial or harmful effect of LCPUFA supplementation on neurodevelopment or visual function in term infants.

In summary the results shown in this systematic review demonstrate evidence that n-3 LCPUFA supplementation to pregnant women determines a modest increases of birth size in their neonates born at term, especially in primigravidas ${ }^{(58,62)}$, independently of low- or high-income populations; Previous meta-analysis reached similar conclusions, basically a small but significant increase in the length of gestation $(\approx 2.5$ days $)^{(25,42-43,47)}$ and a modest increase in infant birth weight $(+50 \mathrm{~g})$, birth length $(+0.48 \mathrm{~cm})$ and head circumference $(+0.69 \mathrm{~cm})$ in the offspring's of women taking DHA supplements ${ }^{(25)}$. The new data emerged from recent randomised clinical trials have not changed these conclusions, suggesting that the observed increases in birth weight and birth length could be the result of the increased duration of gestation $^{(27,42-43)}$.

Despite numerous randomized controlled trials, meta-analysis and meta-regression analysis, data after the addition of a specific amount of LCPUFAs to term infant remain probable but not convincing for a robust effect ${ }^{(45)}$. Post-natal supplementation with LCPUFA does not appear to influence 
infant growth ${ }^{(27,44)}$. The present systematic review concludes there is no effect of prenatal or postnatal n-3 LCPUFA supplementation on physical growth.

\section{Considerations about other new important confounders}

Common polymorphisms of the genes FADS2 (FADS2, encoding $\Delta$-6 desaturase) and FADS1 (FADS1, encoding $\Delta-5$ desaturase) found in about one quarter of the European population, encoding for the key enzymes regulating endogenous LCPUFA synthesis, i.e. delta-6-desaturase and delta-5 desaturase, are associated with markedly reduced plasma LCPUFA concentrations ${ }^{(102)}$. First results suggest marked effects of genetic variation in the FADS gene cluster on relevant clinical end points, including cognitive development, with potentially major importance for public health ${ }^{(103)}$. Koletzko et al. ${ }^{(104)}$ showed a consistent significant association of rare SNP alleles with lower amounts of DHA in red blood cell phospholipids of pregnant women; a modulation of DHA status during pregnancy by frequently occurring FADS genotypes may be of major relevance for child outcomes. These data are results from the NUTRIMENTHE EU Project (Grant Agreement: 212652). Further results will clarify the real power of this genetic effect, present in the $30 \%$ of the population, on the cognitive outcome during development. It is tempting to speculate that genetic heterogeneity in fatty acid metabolism may be one of the reasons, besides differing study design and variable quality, for the apparent inconsistent results of different studies that investigated effects of a perinatal supply of DHA sources on developmental outcome.

\section{Considerations about methodological procedures}

Concerns pertaining to the impact of nutrition on neurodevelopment and cognitive performance have emerged over the past decade, in most cases the focus has been on methodological considerations and limitations of these studies ${ }^{(105-107)}$. The sensitivity of the neuropsychological tests to subtle effects of nutrition ${ }^{(106-107)}$ have been addressed and the need to consider the timing of effects relative to the critical periods involved in brain developmental process have been raised $^{(107)}$. In addition, it is now well recognized that neuropsychological tests should assess the specific neuropsychological domains (perceptual, motor, attention, learning and memory, and executive functions) instead of global cognitive performance; first, to avoid hiding or masking specific effects of the nutritional intervention and secondly to address the need to consider the specific biological mechanisms involved. Cultural local factors need to be considered when comparing similar neuropsychological tests administered in different countries, as well as the practice/learning effect ${ }^{(106)}$, especially if the intention is to test subtle improvements after a nutritional intervention.

A number of novel approaches are now available for the assessment of nutrition-related variations in brain structure and function. RCTs with modest sample sizes $(\mathrm{N}<100)$ should consider a combination of structural MRI and functional MRI with EEG; these would provide the most-comprehensive assessment of brain structure and function and, hence, offer insights into possible neural mechanisms underlying the effect of nutrients on cognition and mental well-being ${ }^{(108)}$. These new techniques in combination with the neuropsychological assessment offer new opportunities to unravel the interaction between nutrition and brain development in the near future.

\section{Implications for future research}

The complexity of brain development process requires special attention. The absence of positive results obtained so far should be analyzed carefully; the existing neuropsychological tests used up to now are likely not sufficiently sensitive to conclude there is "no effect". Novel more function specific approaches that combine the assessment of different neuropsychological domains should be developed considering the potential biological mechanism involved for the specific nutrient-effect to be explored. Furthermore, the combination of new imaging techniques and electrophysiological responses must be promoted as gold-standard methodologies to detect objective nutrient effects on brain development.

Regarding the recent emerging results from different studies, it seems that there is really an optimum DHA level below and above which there may be detrimental consequences to the developing brain; this should be explored in low income populations where risk of abnormal brain development is greatest considering the need for large sample sizes and the evaluation of a dose response.

Analyses of FADS gene variants should be mandatory in all sizeable cohort and intervention studies in order to address the diet and endogenous individual metabolism interactions in defining the potential biological effects of LCPUFA; this should enhance study sensitivity and precision.

\section{Acknowledgements}

The publication of the supplement was supported by PULEVA Food, S.L. No conflicts of interest are declared. All coauthors contributed to the initial protocol of the review. CC, VE and TA were responsible for the literature searched, study selection, methodological quality assessment, and data extraction. HS and RU supervised the methodological quality assessment and all authors contributed to the data interpretation and writing of the final report. CC (coordinator), VE, TA and HS are researchers in the EU Project funded by FP7 European Commission - DG Research. Directorate E - Life Sciences: Theme 2 Food, Agriculture and Fisheries, and Biotechnology. Grant agreement $n^{\circ}$ : FP7-212652-NUTRIMENTHE.

\section{References}

1. Innis SM (2005) Essential fatty acid transfer and fetal development. Placenta 26, S70-S75.

2. Van Houwelingen AC, Sorensen JD, Hornstra G, et al. (1995) Essential fatty acid status in neonates after fish-oil supplementation during late pregnancy. Br J Nutr $\mathbf{7 4}$, 723-731. 
3. Elias SL \& Innis SM (2001) Infant plasma trans, n-6, and n-3 fatty acids and conjugated linoleic acids are related to maternal plasma fatty acids, length of gestation, and birth weight and length. Am J Clin Nutr 73, 807-814.

4. Decsi T, Campoy C \& Koletzko B (2005) Effect of N-3 polyunsaturated fatty acid supplementation in pregnancy: the Nuheal trial. Adv Exp Med Biol 569, 109-113.

5. Krauss-Etschmann S, Shadid R, Campoy C, et al. (2007) Effects of fish-oil and folate supplementation of pregnant women on maternal and fetal plasma concentrations of docosahexaenoic acid and eicosapentaenoic acid: a European randomized multicenter trial. Am J Clin Nutr 85, 1392-1400.

6. Koletzko B, Larque E \& Demmelmair H (2007) Placental transfer of long-chain polyunsaturated fatty acids (LCPUFA). J Perinat Med 35, Suppl 1, S5-11.

7. Larque E, Krauss-Etschmann S, Campoy C, et al. (2006) Docosahexaenoic acid supply in pregnancy affects placental expression of fatty acid transport proteins. Am J Clin Nutr 84, 853-861.

8. Olsen SF, Hansen HS, Sorensen TI, et al. (1986) Intake of marine fat, rich in (n-3) polyunsaturated fatty acids, may increase birthweight by prolonging gestation. Lancet 2, 367-369.

9. Olsen SF (2004) Is supplementation with marine omega-3 fatty acids during pregnancy a useful tool in the prevention of preterm birth? Clin Obstet Gynecol 47, 768-774.

10. Heird WC \& Lapillonne A (2005) The role of essential fatty acids in development. Annu Rev Nutr 25, 549-571.

11. Hadders-Algra M, Bouwstra H, van Goor SA, et al. (2007) Prenatal and early postnatal fatty acid status and neurodevelopmental outcome. J Perinat Med 35, Suppl 1, S28-S34.

12. McCann JC \& Ames BN (2005) Is docosahexaenoic acid, an n-3 long-chain polyunsaturated fatty acid, required for development of normal brain function? An overview of evidence from cognitive and behavioral tests in humans and animals. Am J Clin Nutr 82, 281-295.

13. Uauy R \& Dangour AD (2006) Nutrition in brain development and aging: role of essential fatty acids. Nutr Rev $\mathbf{6 4}$, S24-S33.

14. Hibbeln JR, Ferguson TA \& Blasbalg TL (2006) Omega-3 fatty acid deficiencies in neurodevelopment, aggression and autonomic dysregulation: opportunities for intervention. Int Rev Psychiatry 18, 107-118.

15. Innis SM (2007) Dietary (n-3) fatty acids and brain development. J Nutr 137, 855-859.

16. Schuchardt JP, Huss M, Stauss-Grabo M, et al. (2010) Significance of long-chain polyunsaturated fatty acids (PUFAs) for the development and behaviour of children. Eur J Pediatr 169, 149-164.

17. Clandinin MT, Chappell JE, Leong S, et al. (1980) Extrauterine fatty acid accretion in infant brain: implications for fatty acid requirements. Early Hum Dev 4, 131-138.

18. Martinez M (1992) Tissue levels of polyunsaturated fatty acids during early human development. J Pediatr 120, S129-S138.

19. Innis SM (2009) Omega-3 Fatty acids and neural development to 2 years of age: do we know enough for dietary recommendations? JPGN 48, Suppl 1, S16-S24.

20. Williams C, Birch EE, Emmett PM, et al. (2001) Stereoacuity at age $3.5 \mathrm{y}$ in children born full-term is associated with prenatal and postnatal dietary factors: a report from a populationbased cohort study. Am J Clin Nutr 73, 316-322.

21. Innis SM, Gilley J \& Werker J (2001) Are human milk longchain polyunsaturated fatty acids related to visual and neural development in breast-fed term infants? 139, 532-538.

22. Hibbeln JR, Davis JM, Steer C, et al. (2007) Maternal seafood consumption in pregnancy and neurodevelopmental outcomes in childhood (ALSPAC study): an observational cohort study. Lancet 369, 578-585.

23. Koletzko B, Lien E, Agostoni C, et al. (2008) The roles of long-chain polyunsaturated fatty acids in pregnancy, lactation and infancy: review of current knowledge and consensus recommendations. J Perinat Med 36, 5-14.

24. Gibson RA, Muhlhausler B \& Makrides M (2011) Conversion of linoleic acid and alpha-linolenic acid to long-chain polyunsaturated fatty acids (LCPUFAs), with a focus on pregnancy, lactation and the first 2 years of life. Maternal \& Child Nutrition 7, 17-26.

25. Delgado-Noguera MF, Calvache JA \& Bonfill C (2010) Supplementation with long chain polyunsaturated fatty acids (LCPUFA) to breastfeeding mothers for improving child growth and development. Cochrane Database Syst Rev CD007901.

26. Dziechciarz P, Horvath A \& Szajewska H (2010) Effects of n-3 long-chain polyunsaturated fatty acid supplementation during pregnancy and/or lactation on neurodevelopment and visual function in children: a systematic review of randomized controlled trials. J Am Coll Nutr 29, 443-454.

27. Makrides M, Collins CT \& Gibson RA (2011) Impact of fatty acid status on growth and neurobehavioural development in humans. Matern Child Nutr 7, Suppl 2, 80-88.

28. Uauy RD, Birch DG, Birch EE, et al. (1990) Effect of dietary n-3 fatty acids on retinal function of very low birthweight neonates. Pediatr Research 28, 485-492.

29. Birch DG, Birch EE, Hoffman DR, et al. (1992) Retinal development in very-low-birth-weight infants fed diets differing in omega-3 fatty acids. Invest Ophthalmol Vis Sci 33, 2365-2376.

30. Carlson SE, Werkman SH, Rhodes PG, et al. (1993) Visualacuity development in healthy preterm infants: effect of marine-oil supplementation. Am J Clin Nutr 58, 35-42.

31. Makrides M, Simmer K, Goggin M, et al. (1993) Erythrocyte docosahexaenoic acid correlates with the visual response of the healthy, term infant. Pediatr Res 33, 3242-3253.

32. Agostoni C, Trojan S, Bellu R, et al. (1997) Developmental quotient at 24 months and fatty acid composition of diet in early infancy: a follow up study. Arch Dis Child 76, 421-424.

33. Lucas A, Stafford M, Morley R, et al. (1999) Efficacy and safety of long-chain polyunsaturated fatty acid supplementation of infant formula milk: a randomised trial. Lancet 354, 1948-1954.

34. Hoffman DR, Birch EE, Birch DG, Wheaton DH, et al. (2000) Impact of early dietary intake and blood lipid composition of long-chain polyunsaturated fatty acids on later visual development. JPGN 31, 540-553.

35. Morrow-Tlucak M, Haude RH \& Ernhart CB (1988) Breastfeeding and cognitive development in the first two years of life. Social Science \& Medicine 26, 635-639.

36. Uauy R, Hoffman DR, Mena P, et al. (2003) Term infant studies of DHA and ARA supplementation on neurodevelopment: results of randomized controlled trials. J Pediatr 143, 4, S17-S25.

37. Uauy R (1990) Are omega-3 fatty acids required for normal eye and brain development in the human? J Pediatr Gastroenterol Nutr 11, 296-302.

38. Caspi A, Williams B, Kim-Cohen J, et al. (2007) Moderation of breastfeeding effects on the IQ by genetic variation in 
fatty acid metabolism. Proc Natl Acad Sci U S A $\mathbf{1 0 4}$ 18860-18865.

39. Steer CD, Smith DG, Emmett PM, et al. (2010) FADS2 Polymorphisms Modify the Effect of Breastfeeding on Child IQ. PLOS ONE 5, e11570.

40. Anderson RE, Maude MB, Alvarez RA, et al. (1999) A hypothesis to explain the reduced blood levels of docosahexaenoic acid in inherited retinal degenerations caused by mutations in genes encoding retina-specific proteins. Lipids 34, S235-S237.

41. Robinson KA \& Dickersin K (2002) Development of a highly sensitive search strategy for the retrieval of reports of controlled trials using PubMed. International Journal of Epidemiology 31, 150-153.

42. Horvath A, Koletzko B \& Szajewska H (2007) Effect of supplementation of women in high-risk pregnancies with longchain polyunsaturated fatty acids on pregnancy outcomes and growth measures at birth: a meta-analysis of randomized controlled trials. Br J Nutr 98, 253-259.

43. Szajewska H, Horvath A A \& Koletzko B (2006) Effect of n-3 long-chain polyunsaturated fatty acid supplementation of women with low-risk pregnancies on pregnancy outcomes and growth measures at birth: a meta-analysis of randomized controlled trials. Am J Clin Nutr 83, 1337-1344.

44. Beyerlein A, Hadders-Algra M, Kennedy K, et al. (2010) Infant formula supplementation with long-chain polyunsaturated fatty acids has no effect on Bayley developmental scores at 18 months of age-IPD meta-analysis of 4 large clinical trials. J Pediatr Gastroenterol Nutr 50, 79-84.

45. Simmer K, Patole SK \& Rao SC (2008) Longchain polyunsaturated fatty acid supplementation in infants born at term. Cochrane Database Syst Rev CD000376.

46. Blau-Hospers CH \& Hadders-Algra M (2005) Developmental Medicine \& Child Neurology 47, 421-432

47. Makrides M, Duley L \& Olsen SF (2006) Marine oil, and other prostaglandin precursor, supplementation for pregnancy uncomplicated by pre-eclampsia or intrauterine growth restriction. Cochrane Database Syst Rev 3, CD003402.

48. Dunstan JA, Simmer K, Dixon G, et al. (2008) Cognitive assessment of children at age 2(1/2) years after maternal fish oil supplementation in pregnancy: a randomised controlled trial. Arch Dis Child Fetal Neonatal Ed 93, F45-F50.

49. Malcolm CA, Hamilton R, McCulloch DL, et al. (2003b) Scotopic electroretinogram in term infants born of mothers supplemented with docosahexaenoic acid during pregnancy. Invest Ophthalmol Vis Sci 44, 3685-3691.

50. Malcolm CA, McCulloch DL, Montgomery C, et al. (2003a) Maternal docosahexaenoic acid supplementation during pregnancy and visual evoked potential development in term infants: a double blind, prospective, randomised trial. Arch Dis Child Fetal Neonatal Ed 88, F383-F390.

51. Innis SM \& Friesen RW (2008) Essential n-3 fatty acids in pregnant women and early visual acuity maturation in term infants. Am J Clin Nutr 87, 548-557.

52. Judge MP, Harel O \& Lammi-Keefe CJ (2007a) A docosahexaenoic acid-functional food during pregnancy benefits infant visual acuity at four but not six months of age. Lipids 42, 117-122.

53. Judge MP, Harel O \& Lammi-Keefe CJ (2007b) Maternal consumption of a docosahexaenoic acid-containing functional food during pregnancy: benefit for infant performance on problem-solving but not on recognition memory tasks at age 9 mo. Am J Clin Nutr 85, 1572-1577.

54. Tofail F, Kabir I, Hamadani JD, et al. (2006) Supplementation of fish-oil and soy-oil during pregnancy and psychomotor development of infants. J Health Popul Nutr 24, 48-56.

55. Escolano-Margarit MV, Ramos R, Beyer J, et al. (2011) Prenatal DHA Status and Neurological Outcome in Children at Age 5.5 Years Are Positively Associated. J Nutr 141, 1216-1223.

56. Campoy C, Escolano-Margarit MV \& Ramos R (2011) Effects of prenatal fish oil and 5-methyltetrahidrofolate supplementation on cognitive development of children at $6 \frac{1}{2}$ years of age. Am J Clin Nutr (Epub ahead for print).

57. Olsen SF, Sorensen JD, Secher NJ, et al. (1992) Randomised controlled trial of effect of fish-oil supplementation on pregnancy duration. Lancet 339, 1003-1007.

58. Ramakrishnan U, Stein AD, Parra-Cabrera S, et al. (2010) Effects of docosahexaenoic acid supplementation during pregnancy on gestational age and size at birth: randomized, double-blind, placebo-controlled trial in Mexico. Food Nutr Bull 31, S108-S116.

59. Courville AB, Harel O \& Lammi-Keefe CJ (2011) Consumption of a DHA-containing functional food during pregnancy is associated with lower infant ponderal index and cord plasma insulin concentration. Br J Nutr 27, 1-5.

60. Smuts CM, Borod E, Peeples JM, et al. (2003a) High-DHA eggs: feasibility as a means to enhance circulating DHA in mother and infant. Lipids 38, 407-414.

61. Smuts CM, Huang M, Mundy D, et al. (2003b) A randomized trial of docosahexaenoic acid supplementation during the third trimester of pregnancy. Obstet Gynecol 469,479.

62. Stein AD, Wang M, Martorell R, et al. (2011) Growth to Age 18 Months Following Prenatal Supplementation with Docosahexaenoic Acid Differs by Maternal Gravidity in Mexico. J Nutr 141, 316-320.

63. Sanjurjo P, Ruiz-Sanz JI, Jimeno P, et al. (2004) Supplementation with docosahexaenoic acid in the last trimester of pregnancy: maternal-fetal biochemical findings. J Perinat Med 32, 132-136.

64. Makrides M, Gibson RA, McPhee AJ, et al. (2010) Effect of DHA Supplementation During Pregnancy on Maternal Depression and Neurodevelopment of Young Children A Randomized Controlled Trial. JAMA 304, 1675-1683.

65. Smithers LG, Gibson RA \& Makrides M (2011) Maternal supplementation with docosahexaenoic acid during pregnancy does not affect early visual development in the infant: a randomized controlled trial. Am J Clin Nutr 93, 1293-1299.

66. Helland IB, Saugstad OD, Smith L, et al. (2001) Similar effects on infants of n-3 and n-6 fatty acids supplementation to pregnant and lactating women. Pediatrics 108, E82-E95.

67. Helland IB, Smith L, Saarem K, et al. (2003) Maternal supplementation with very-long-chain n-3 fatty acids during pregnancy and lactation augments children's IQ at 4 years of age. Pediatrics 111, e39-e44.

68. Helland IB, Smith L, Blomen B, et al. (2008) Effect of supplementing pregnant and lactating mothers with $n-3$ verylong-chain fatty acids on children's IQ and body mass index at 7 years of age. Pediatrics 122, e472-e 479 .

69. Bergmann LR, Bergmann KE, Haschke-Becher E, et al. (2007) Does maternal docosahexaenoic acid supplementation during pregnancy and lactation lower BMI in late infancy. J Perinat Med 35, 295-300.

70. Jensen CL, Voigt RG, Prager TC, et al. (2005) Effects of maternal docosahexaenoic acid intake on visual function and neurodevelopment in breastfed term infants. Am J Clin Nutr 82, 125-132.

71. Lauritzen L, Jorgensen MH, Mikkelsen TB, et al. (2004) Maternal fish oil supplementation in lactation: effect on 
visual acuity and n-3 fatty acid content of infant erythrocytes. Lipids 39, 195-206.

72. Lauritzen L, Jørgensen MH, Olsen SF, et al. (2005) Maternal fish oil supplementation in lactation: effect on developmental outcome in breast-fed infants. Reprod Nutr Dev 45 , 535-547.

73. Cheatham CL, Nerhammer AS, Asserhoj M, et al. (2011) Fish oil supplementation during lactation: effects on cognition and behavior at 7 years of age. Lipids 46, 637-645.

74. Jensen CL, Voigt RG, Llorente AM, et al. (2010) Effects of early maternal docosahexaenoic acid intake on neuropsychological status and visual acuity at five years of age of breast-fed term infants. J Pediatr 157, 900-905.

75. Drover JR, Hoffman DR, Castaneda YS, et al. (2011) Cognitive function in 18-month-old term infants of the DIAMOND study: a randomized, controlled clinical trial with multiple dietary levels of docosahexaenoic acid. Early Hum Dev 87, 223-230.

76. Birch EE, Carlson SE, Hoffman DR, et al. (2010) The DIAMOND (DHA Intake And Measurement Of Neural Development) Study: a double-masked, randomized controlled clinical trial of the maturation of infant visual acuity as a function of the dietary level of docosahexaenoic acid. Am J Clin Nutr 91, 848-859.

77. De Jong C, Kikkert HK, Fidler V, et al. (2010) The Groningen LCPUFA study: no effect of postnatal long-chain polyunsaturated fatty acids in healthy term infants on neurological condition at 9 years. Br J Nutr 104, 566-572.

78. Birch EE, Garfield S, Castaneda Y, et al. (2007) Visual acuity and cognitive outcomes at 4 years of age in a double-blind, randomized trial of long-chain polyunsaturated fatty acidsupplemented infant formula. Early Hum Dev 83, 279-284.

79. Bouwstra H, Dijck-Brouwer DA, Boehm G, et al. (2005) Acta Paediatr 94, 26-32.

80. Auestad N, Scott DT, Janowsky JS, et al. (2003) Visual, cognitive, and language assessments at 39 months: a follow-up study of children fed formulas containing long-chain polyunsaturated fatty acids to 1 year of age. Pediatrics 112, e177-e183.

81. Lucas A, Morley R, Stephenson T, et al. (2002) Long-chain polyunsaturated fatty acids and infant formula. Lancet 360, 1178-1185.

82. Agostoni C, Riva E, Scaglioni S, et al. (2000) Dietary fats and cholesterol in Italian infants and children. Am J Cli Nutr $\mathbf{7 2}$, 1384S-1391S.

83. Birch EE, Garfield S, Hoffman DR, et al. (2000) A randomised controlled trial of early dietary supply of LCPUFA and mental development in term infants. Dev Med Child Neurol 42, 174-181.

84. Makrides M, Neumann MA, Simmer K, et al. (2000) A appraisal of the role of long-chain polyunsaturated fatty acids on neural indices of term infants: a randomised controlled trial. Pediatrics 105, 32-38.

85. Makrides M, Neumann MA, Simmer K, et al. (1999) Dietary long chain polyunsaturated fatty acids do not influence growth of term infants: a randomised clinical trial. Pediatrics 104, 468-475.

86. Birch EE, Hoffman DR, Uauy R, et al. (1998) Visual acuity and the essentiality of docosahexaenoic acid and arachidonic acid in the diet of term infants. Pediatr Res 44, 201-209.

87. Scott DT, Janowsky JS, Carroll RE, et al. (1998) Formula supplementation with long-chain polyunsaturated fatty acids: are there developmental benefits? Pediatrics 102, e59.

88. Auestad N, Montalto MB, Hall RT, et al. (1997) Visual acuity, erythrocyte fatty acid composition, and growth in term infants fed formulas with long-chain polyunsaturated fatty acids for one year. Ped Res $\mathbf{4 1}, 1-10$.

89. Agostoni C, Trojan S, Bellu R, et al. (1995) Neurodevelopmental quotient of healthy term infants at 4 months and feeding practice: the role of long-chain polyunsaturated fatty acids. Ped Res 38, 262-266.

90. Birch EE, Castañeda Y, Wheaton DH, et al. (2005) Visual maturation of term infants fed long-chain polyunsaturated fatty acid-supplemented or control formula for $12 \mathrm{mo}$. Am J Clin Nutr 81, 871-879.

91. Ben XM, Zhou XY, Zhao WH, et al. (2004) Growth and development of term infants fed with milk with long-chain polyunsaturated fatty acid supplementation. Chinese Medical Journal 117, 1268-1270.

92. Auestad N, Halter R, Hall RT, et al. (2001) Growth and development in term infants fed long-chain polyunsaturated fatty acids: a double-masked, randomized, parallel, prospective, multivariate study. Pediatrics 108, 372-381.

93. Lapillonne A, Brosssard N, Claris O, et al. (2000) Erythrocyte fatty acid composition in term infants fed human milk or a formula enriched with a low eicosapentanoic acid fish oil for 4 months. European Journal of Pediatrics 159, 49-53.

94. Morris G, Moorcraft J, Mountjoy A, et al. (2000) A novel infant formula milk with added long-chain polyunsaturated fatty acids from single-cell sources: a study of growth, satisfaction and health. Eur J Clin Nutr 54, 883-886.

95. Willatts P, Forsyth JS, DiModugno MK, et al. (1998) Effect of long-chain polyunsaturated fatty acids in infant formula on problem solving at 10 months of age. Lancet 352, 688-691.

96. Carlson SE, Ford AJ, Werkman SH, et al. (1996) Visual acuity and fatty acid status of term infants fed human milk and formulas with and without docosahexaenoate and arachidonate from egg yolk lecithin. Ped Res 39, 882-888.

97. Makrides M, Neumann M, Simmer K, et al. (1995) Pater J, Gibson R. Are long chain polyunsaturated fatty acids essential nutrients in infancy? Lancet 345, 1463-1468.

98. Makrides M (2008) Outcomes for mothers and their babies: do n-3 long-chain polyunsaturated fatty acids and seafoods make a difference? J Am Diet Assoc 108, 1622-1626.

99. Hibbeln JR, Davis JM, Steer C, et al. (2007) Maternal seafood consumption in pregnancy and neurodevelopmental outcomes in childhood (ALSPAC study): an observational cohort study. Lancet 369, 578-585.

100. Dangour AD \& Uauy R (2008) N-3 long-chain polyunsaturated fatty acids for optimal function during brain development and ageing. Asia Pac J Clin Nutr 17, Suppl 1, 185-188.

101. Koletzko B, Agostoni C, Carlson SE, et al. (2001) Long chain polyunsaturated fatty acids (LCPUFA) and perinatal development. Acta Paediatr 90, 460-464.

102. Lattka E, Eggers S, Moeller G, et al. (2010) A common FADS2 promoter polymorphism increases promoter activity and facilitates binding of transcription factor ELK1. J Lipid Res 51, 182-191.

103. Glaser C, Lattka E, Rzehak P, et al. (2011) Genetic variation in polyunsaturated fatty acid metabolism and its potential relevance for human development and health. Matern Child Nutr 7, Suppl 2, 27-40.

104. Koletzko B, Lattka E, Zeilinger S, et al. (2011) Genetic variants of the fatty acid desaturase gene cluster predict amounts of red blood cell docosahexaenoic and other polyunsaturated fatty acids in pregnant women: findings from the Avon Longitudinal Study of Parents and Children. Am J Clin Nutr 93, 211-219. 
105. Burgard P (2003) Critical evaluation of the methodology employed in cognitive development trials. Acta Paediatr suppl 92, 6-10.

106. Schmitt JA, Benton D \& Kallus KW (2005) General methodological considerations for the assessment of nutritional influences on human cognitive functions. Eur J Nutr $\mathbf{4 4}$, 459-464.
107. Hughes D \& Bryan J (2003) The Assessment of Cognitive Performance in Children: Considerations for Detecting Nutritional Influences. Nutrition Reviews 61, 413-422.

108. Tomas Paus (2010) A primer for brain imaging: a tool for evidence-based studies of nutrition? Nutrition Reviews $\mathbf{6 8}$, Suppl 1, S29-S37. 